Pege 1 of 2

ECN

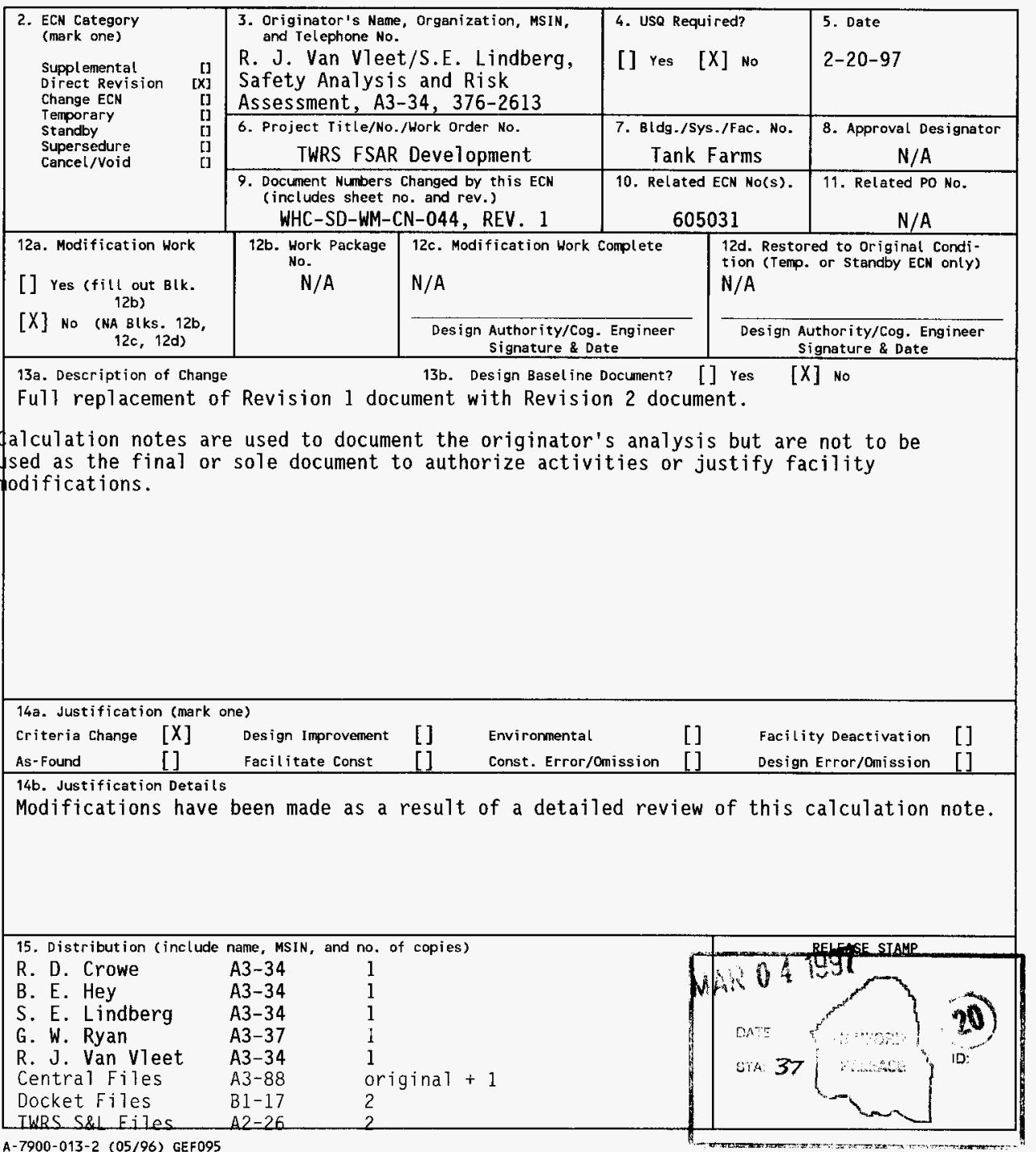




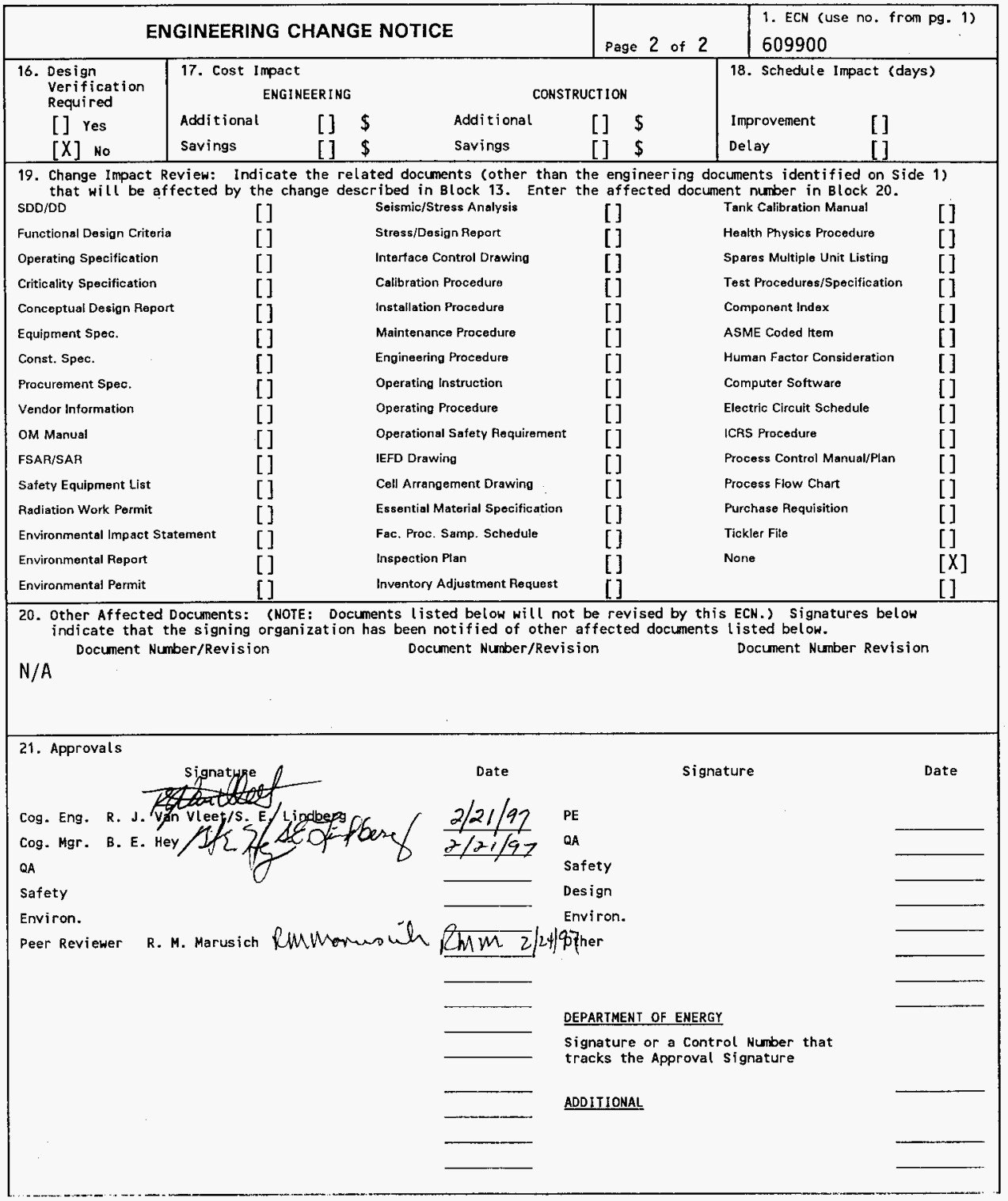




\section{Calculation Notes That Support Accident Scenario and Consequence Development for the Steam Intrusion From Interfacing Systems Accident}

G. W. Ryan

Duke Engineering Services Hanford, Richland, WA 99352

R. J. Van Vleet, R. D. Crowe, and S.E. Lindberg

Fluor Daniel Northwest, Richland, WA 99352

U.S. Department of Energy Contract DE-AC06-96RL13200

$\begin{array}{lll}\text { EDT/ECN: } & 609900 & \text { UC: } 510 \\ \text { Org Code: } & 403 & \text { Charge Code: P2TY00 } \\ \text { B\&R Code: } & \text { EW3120071 } & \text { Total Pages: }-6770\end{array}$

Key Words: pipe, pipeline, piping, steam, steam jet, tank farms, TWRS

Abstract: This document supports the development and presentation of the following accident scenario in the TWRS Final Safety Analysis

Report:

\section{Steam Intrusion From Interfacing Systems.}

The calculations needed to quantify the risk associated with this accident scenario are included within.

TRADEMARK DISCLAIMER. Reference herein to any specific comercial product, process, or service by trade name, trademark, manufacturer, or otherwise, does not necessarily constitute or imply its endorsement, recommendation, or favoring by the United States Government or any agency thereof or its contractors or subcontractors.

Printed in the United States of America. To obtain copies of this document, contact: WHC/BCS Document Control Services, P.0. Box 1970, Mailstop H6-08, Richland WA 99352, Phone (509) 372-2420; Fax (509) 376-4989.
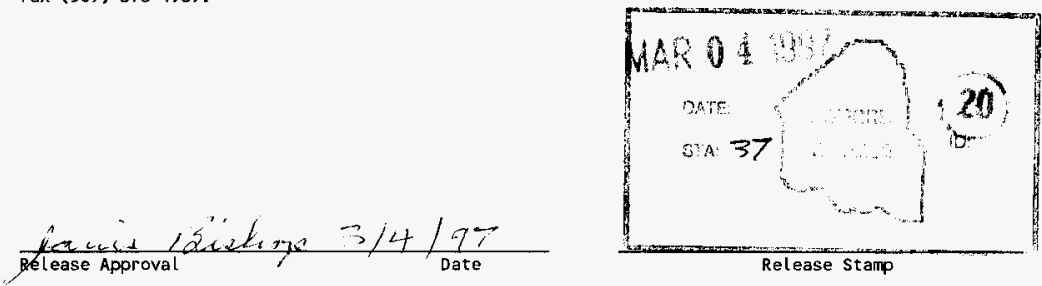


\section{RECORD OF REVISION}

(2) Title

Calculation Notes That Support Accident Scenario and Consequence Development for the Steam Intrusion From Interfacing Systems Accident

CHANGE CONTROL RECORD

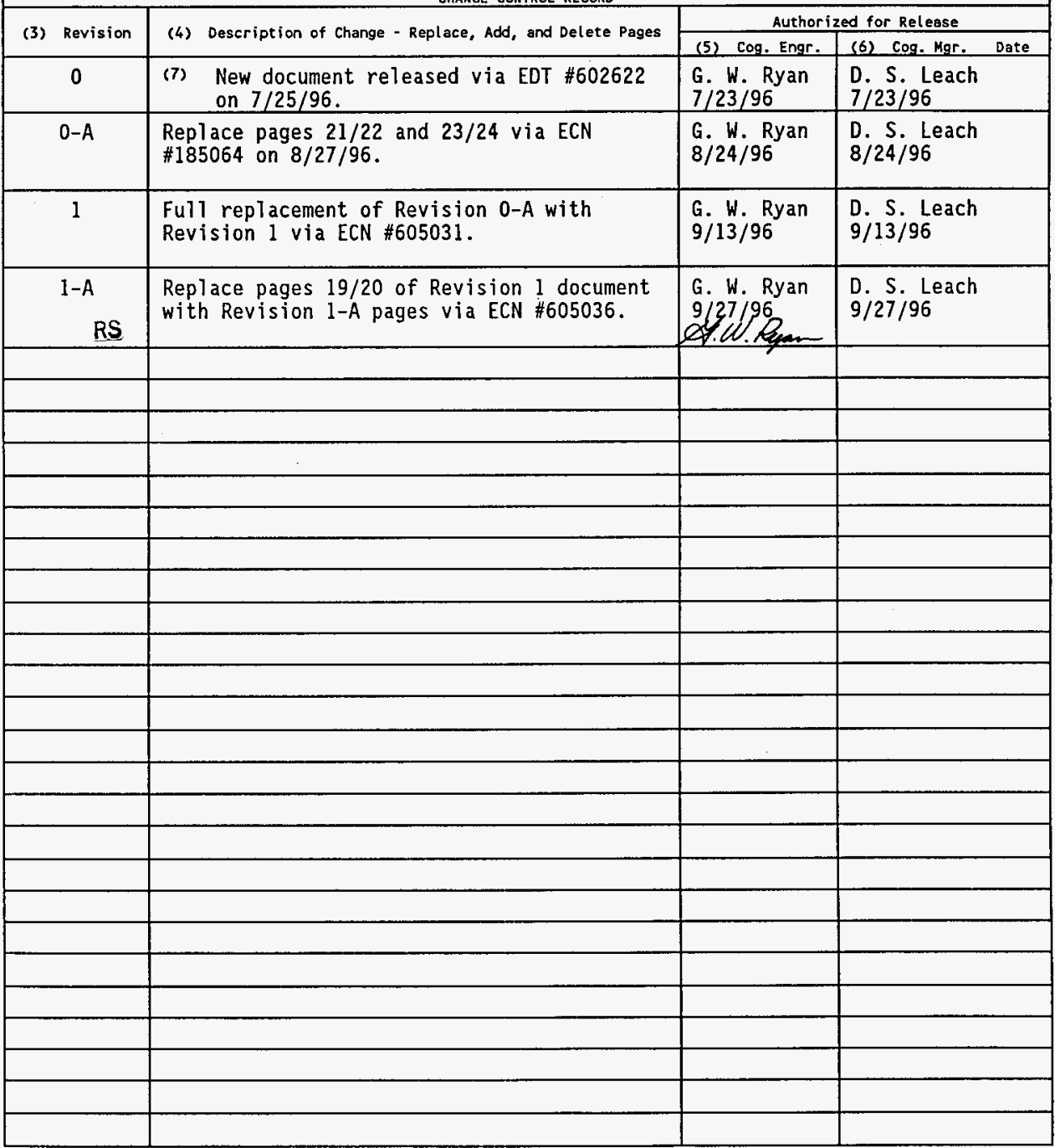




\section{RECORD OF REVISION}

(1) Document Number

HNF-SD-WM-CN-044

Page 2

(2) Title

Calculation Notes that Support Accident Scenario and Consequence Development for the Steam Intrusion from Interfacing Systems Accident

CHANGE CONTROL RECORD

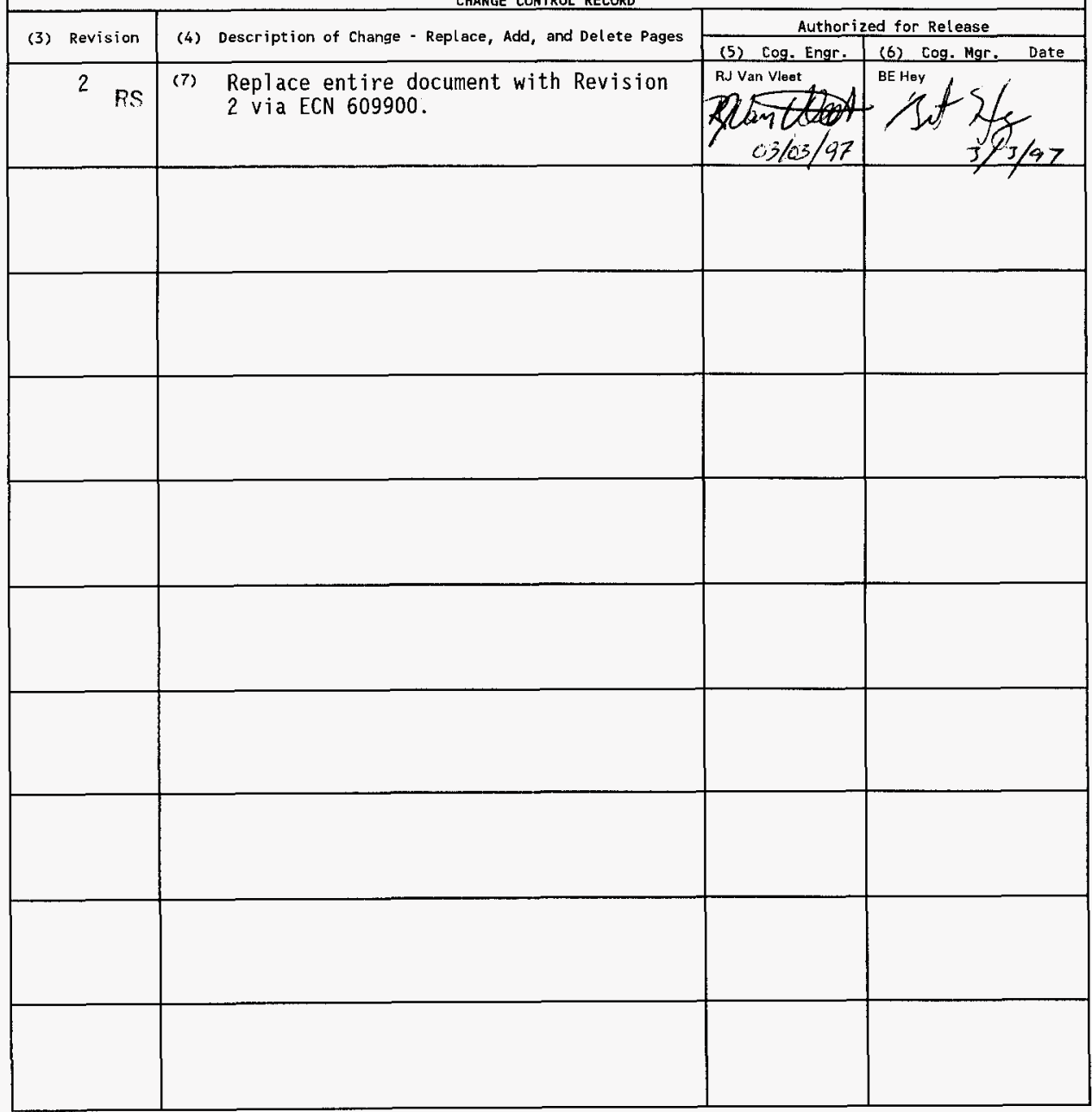


HNF-SD-WM-CN-044 REV 2

\section{CALCULATION NOTES THAT SUPPORT ACCIDENT SCENARIO AND CONSEQUENCE DEVELOPNENT FOR THE STEAM INTRUSION FROM INTERFACING SYSTEMS ACCIDENT \\ REVISION 2}

Tank Waste Remediation System Final Safety Analysis Report Project Specialty Engineering

February 1997 
HNF-SD-WM-CN-044 REV 2

This page intentionally left blank. 


\section{CONTENTS}

1.0 INTRODUCTION AND PURPOSE ................... 7 of 18

1.1 ACCIDENT SCENARIO DESCRIPTION . . . . . . . . . . 7 of 18

1.2 ACCIDENT FREQUENCY DEVELOPMENT . . . . . . . . . . . . . 8 of 18

1.3 ASSUMPTIONS . . . . . . . . . . . . . 8 of 18

1.4 METHODOLOGY AND ANALYSIS TECHNIQUES . . . . . . . . . 11 of 18 1.4.1 Analysis Results .............. 12 of 18

1.5 RADIOLOGICAL AND TOXICOLOGICAL SOURCE TERM ........ . 13 of 18

1.6 CALCULATED RADIOLOGICAL DOSES . . . . . . . . . . 14 of 18 1.6.1 Input Data . . . . . . . . . . . . . . . 14 of 18

1.6.2 Calculations.............. . . 15 of 18

1.7 CALCULATED TOXICOLOGICAL DOSES . . . . . . . . . 16 of 18

1.7.1 Input Data . . . . . . . . . . . . . . . 16 of 18

1.7 .2 Calculations ................. 16 of 18

1.8 RESULTS .................... . . 17 of 18

1.8.1 Radiological ................ . . 17 of 18

1.8 .2 Toxicological ........................... 17 of 18

1.9 CONCLUSIONS .................. 17 of 18

1.10 REFERENCES ..................... 18 of 18

\section{APPENDICES}

A INFORMATION VALIDATION FORMS . . . . . . . . . . . . . . . . A-1

B HAZARD ANALYSIS RESULTS FOR INTERFACING FACILITIES

THAT USE STEAM JETS . . . . . . . . . . . . . . . . . . B-1

C WASTE TANK HEADSPACE GAS VENT FlOW DURATION . . . . . . . . . . . . c-1

D PARTITION FRACTION DISCUSSION . . . . . . . . . . . . . . D-1

E CALCULATION NOTES FOR STEAM INTRUSION . . . . . . . . . . . E-1

F CONSEQUENCE CALCULATIONS FOR STEAM INTRUSION . . . . . . . . . F-1

G PEER REVIEW AND HEDOP REVIEW CHECKLIST . . . . . . . . . . . . G-1 
HNF-SD-WM-CN-044 REV 2

\section{LIST OF TABLES}

1.9-1. Summary Table of Accident Consequences . . . . . . . . . 18 of 18 B-1. Hazard Analysis Results for Interfacing Facilities That Use Steam Jets ... . . . . . . . . . . . . . . B-3

$\mathrm{C}-1$. Waste Tank Headspace Gas Vent Flow Duration Table. . . . . . . . C-3 


\section{HNF-SD-WM-CN-044 REV 2}

\section{LIST OF TERMS}

$\begin{array}{ll}\text { cfm } & \text { cubic feet per minute } \\ \text { FSAR } & \text { final safety analysis report } \\ \text { HEDOP } & \text { Hanford Environmental Dose Overview Panel } \\ \text { rem } & \text { radiation effective man } \\ \text { DST } & \text { double-shell tank } \\ \text { PFP } & \text { Plutonium Finishing Plant } \\ \text { PUREX } & \text { Plutonium-Uranium Extraction Plant } \\ \text { SST } & \text { single-shell tank } \\ \text { SV } & \text { sievert } \\ \text { TWRS } & \text { Tank Waste Remediation System } \\ \text { WHC } & \text { Westinghouse Hanford Company }\end{array}$


HNF-SD-WM-CN-044 REV 2

This page intentionally left blank. 


\section{CALCULATION NOTES THAT SUPPORT ACCIDENT SCENARIO AND CONSEQUENCE DEVELOPMENT FOR THE STEAM INTRUSION FROM INTERFACING SYSTEMS ACCIDENT}

\subsection{INTRODUCTION AND PURPOSE}

This document supports the development and presentation of the following accident scenario in the TWRS Final Safety Analysis Report (FSAR):

\section{Steam Intrusion From Interfacing Systems.}

The calculations needed to quantify the risk associated with this accident scenario are included in the following sections to aid in the understanding of this accident scenario.

Information validation forms citing assumptions that were approved for use specifically in this analysis are included in Appendix A. Copies of these forms are also on file with TWRS Project Files.

Calculations performed in this document, in general, are expressed in traditional (English) units to aid understanding of the accident scenario and related parameters.

\subsection{ACCIDENT SCENARIO DESCRIPTION}

The hazard analysis performed for the tank farms identified operations at interfacing facilities or systems that may impact tank farm operations. This document investigates steam jet transfers from interfacing facilities. Potential accident causes and conditions relating to steam jet waste transfers are documented in Appendix B.

It is postulated that the introduction of raw steam (at the end of a waste transfer) into a waste storage tank may increase the tank headspace pressure and result in an aerosol release through unfiltered pathways (e.g., cover blocks, and capped risers). Additionally, if the differential pressure in the tank is shown to be approximately $10^{\prime \prime}$ water gauge, HEPA filter rupture is considered to occur and the quantity of waste from a HEPA filter rupture should be added to the inventory released from the headspace air. An accident scenario such as this may potentially result in significant onsite consequences.

Interfacing facilities or systems that could potentially impact tank farms by the use of a steam jet include Z-Plant (PFP), 222-S Laboratory, 242-A Evaporator, PUREX, and T-PIant. The 244-AR Vault is not considered an interfacing facility (since it is a TWRS facility) but the potential flowrate of steam from this facility to tank farms was considered to be bounding in this analysis (see Assumptions, Section 1.3). This is considered appropriate since steam has not been physically blanked-off to this facility and future transfers of waste out of this facility will most likely be initiated by the steam jet transfer method. Performing the analysis in this manner allows maximum flexibility in future operations.

In the scenario analyzed, a liquid waste transfer to a double-shell tank is initiated from a process facility (e.g., the 242-A Evaporator) using a steam jet as the motive force to move the i iquid. After the waste has been 
transferred, the steam jet is not shut off (as a result of operator error or equipment failure) and pure steam is routed to the headspace of the receiving tank. It is assumed that 90 psig saturated steam is exhausted into the headspace of a ful1 double-shel1 tank at a flow rate of $2,4001 \mathrm{~b}_{\mathrm{m}} / \mathrm{hr}$.

Both double-shell tanks and double-contained receiver tanks may receive steam jet waste transfers. A double-shell tank was chosen to be analyzed since it has a potentially larger headspace (allowing for more particulates in a release). Lesser consequences would be calculated for a double-contained receiver tank, given the reduced headspace available.

\subsection{ACCIDENT FREQUENCY DEVELOPMENT}

The prior operational history of the tank farms was the single factor considered when a frequency of anticipated was qualitatively assigned to this accident scenario. Although no written documentation of previous incidents could be located, prior operational history has shown that a scenario such as this is possible today (due to the use of steam jets for transferring waste).

The frequency of this accident will diminish as the use of steam jets from process facilities is further limited due to ongoing and future decontamination and decommissioning activities.

The consequences associated with this accident scenario are compared to the risk acceptance guidelines for anticipated accidents as provided in WHC-CM-4-46, Rev. 1.

\subsection{ASSUNPTIONS}

The following assumptions are considered in the analysis of this accident scenario:

A The saturated steam in this accident scenario is assumed to behave as an ideal gas, so ideal gas relationships hold (i.e., $P V=n R T$ ).

B The injection of steam into the tank headspace is conservatively assumed to be adiabatic (i.e., no heat transfer to the tank walls or waste surface).

C Saturated steam is injected into the tank headspace (not into the waste.)

D The steam introduced into the headspace mixes perfectly with the headspace air. The heat released from the steam is assumed to be absorbed uniformly by the headspace constituents.

E The saturated steam flow rate, mdot, introduced into the tank headspace is 2,400 $1 \mathrm{bm} / \mathrm{hr}\left(0.6671 \mathrm{~b}_{\mathrm{m}} / \mathrm{sec}\right)$ from IVF-Chapter 3-07 in Appendix $A$. This flow rate is considered to bound steam jet transfers from the two facilities identified with steam intrusion potential, 242-A Evaporator (200E) and PFP (200W).

F The saturated steam pressure is 90 psig ( 105 psia) from IVF-Chapter 3-07 in Appendix A. Facilities using process steam have equipment (pressure reducing valves, etc.) to ensure that the steam used for a particular process is at the correct pressure 
(e.g., 90 psig for the 242 Evaporator and 50 psig for PFP). The higher steam pressure would heat up the headspace gases faster (the enthalpy of 225 psig steam is higher than 90 psig steam) resulting in less than a $5 \%$ increase in the 15 minute averaged flow rate.

G The saturated steam is introduced into a partially full double-shell tank. The headspace volume, vol hs, is calculated here:

$$
\begin{aligned}
\text { vol hs }_{\text {hs }} & =\left(1.406 * 10^{6} \mathrm{gal}\right)-(\text { waste depth }) *(2750 \mathrm{gal} / \mathrm{in}) \\
& =\left(1.406 * 10^{6} \mathrm{gal}\right)-(212 \mathrm{in}) *(2750 \mathrm{gal} / \mathrm{in}) \\
& =823,200 \mathrm{gal}=110,000 \mathrm{ft}^{3}
\end{aligned}
$$

$\mathrm{H}$ The headspace air temperature $\left(T_{h s}\right)$ is assumed to be initially at $150{ }^{\circ} \mathrm{F}\left(610^{\circ} \mathrm{R}\right)$.

I The double-shell tank is assumed to be passively ventilated (i.e., ventilation system is shutdown) with HEPA filters installed in the ventilation system. No credit is taken for the HEPA filters in mitigating the release, but the radioactive and toxic material previously trapped by the HEPA filters is included in the release.

$\mathrm{J}$ Initial pressure inside tank headspace $\left(P_{h s}\right)$ is atmospheric at 14.7 psia.

$K$ To obtain the value of the flow coefficient for the amount of gas that will leave the tank through the unfiltered in-leakage pathways the following modified Darcy equation is used (Crane, eq. 3-20):

$$
\begin{aligned}
& W_{\text {vent }}=c_{\mathrm{vd}} \sqrt{\Delta P \rho_{\mathrm{ai} r}} \\
& c_{\mathrm{vd}}=\frac{W_{\text {vent }}}{\sqrt{\Delta P_{\text {norm }} \rho_{\mathrm{air}}}} \\
& c_{\mathrm{vd}}=87.7 \frac{\mathrm{ft}^{3}}{\mathrm{sec}}\left[\frac{\mathrm{atm} \mathrm{tb}}{\mathrm{ft}^{3}}\right]^{-0.5}
\end{aligned}
$$

where:

$$
\begin{aligned}
W_{\text {vent }} & =100 \mathrm{cfm}=1.67 \frac{\mathrm{ft}^{3}}{\mathrm{sec}} \\
\Delta P_{\text {norm }} & =2 \mathrm{in} . W G=0.0049 \mathrm{~atm} \\
\rho_{\text {air }} & =0.073 \frac{\mathrm{lb}}{\mathrm{ft}^{3}} \text { at } 80 \mathrm{~F}
\end{aligned}
$$


$\mathrm{L} \quad$ Credit is taken for flow out a ventilation duct pathway during the pressurization by doubling the vent coefficient.

M The atmosphere in the headspace during the accident is treated as an ideal gas comprised of air and steam with the following properties (Cengel and Boles, 1994):

The density of the air in the headspace, rho air, is a function of the headspace temperature, headspace pressure and the number of moles of air left in the headspace.

$$
\begin{aligned}
& \mathrm{cp}_{\mathrm{air}}=0.235 \mathrm{BTU} / 1 \mathrm{~b}_{\mathrm{m}}-{ }^{\circ} \mathrm{F} \\
& \mathrm{mw}_{\text {air }}=28.971 \mathrm{~b}_{\mathrm{m}} / 1 \mathrm{bmole}
\end{aligned}
$$

The steam introduced into the headspace also treated as an ideal gas with the following properties (Cengel and Boles, 1994):

The density of the steam, rho steam, is a function of the headspace temperature, headspace pressure and the number of moles left in the headspace. Treating steam as an ideal gas over estimates the density by less than $2 \%$ at the initial temperature and under estimates the density by $6 \%$ at the maximum transient temperature as compared to the actual steam tables.

$$
\begin{aligned}
\mathrm{C} \mathrm{p}_{\text {steam }} & =0.44 \mathrm{BTU} / 1 \mathrm{~b}_{\mathrm{m}}{ }^{\circ} \mathrm{F} \\
\mathrm{mw}_{\text {steam }} & =18.0151 \mathrm{~b}_{\mathrm{m}} / 1 \mathrm{bmole}
\end{aligned}
$$

$\mathrm{N}$ Mass and number of moles of air initially in the headspace:

$$
\begin{aligned}
\mathrm{m}_{\text {air }} & =\rho_{\text {air }}\left(150^{\circ} \mathrm{F}\right) \mathrm{ft}^{\mathrm{vol}} \mathrm{l}_{\mathrm{ps}} \\
& \left.=\left(0.055 \mathrm{lb} / \mathrm{ft}^{3}\right)\left(10 \times 10^{5} \mathrm{ft}^{3}\right)\right] \\
& =7,160 \mathrm{~b} \\
\mathrm{n}_{\text {air }} & =\mathrm{m}_{\text {air }} / \mathrm{mw}_{\text {air }} \\
& =2471 \mathrm{bm} \text { moles }
\end{aligned}
$$

0 Standard steam tables are used to find enthalpy of saturated steam (Cengel and Boles, 1994).

$$
\begin{aligned}
& h_{\mathrm{g}}(90 \mathrm{psig})=1188.8 \mathrm{BTU} / 1 \mathrm{~b}_{\mathrm{m}} \\
& \mathrm{h}_{\mathrm{g}}(150 \mathrm{~F})=1126.1 \mathrm{BTU} / 1 \mathrm{~b}_{\mathrm{m}}
\end{aligned}
$$

P A constant heat addition from the steam is assumed, calculated as shown: 


\section{HNF-SD-WM-CN-044 REV 2}

$$
\begin{aligned}
\Delta q_{\text {released from steam }} & =m_{\text {steam }}\left(h_{g \text { on psia) }}-h_{g \text { (150F) }}\right) \\
& =\left(0.667 \frac{1 b_{m}}{s}\right)\left(1188.8 \frac{B t u}{1 b_{m}}-1126.1 \frac{B t u}{1 b_{m}}\right) \\
& =41.8 \frac{B t u}{s}
\end{aligned}
$$

Q The universal gas constant, $R^{*}=0.73023\left(\mathrm{ft}^{3} \mathrm{~atm}\right) /\left(1 \mathrm{bmole}-{ }^{\circ} \mathrm{R}\right)$.

\subsection{METHODOLOGY AND ANALYSIS TECHNIQUES}

Using the assumptions described in Section 1.3, the dynamic behavior of the steam intrusion into the tank headspace is analyzed using the ideal gas 1 aw and the principles of conservation of energy and mass. During each time step in the calculation, the intruded steam adds mass and energy to the totals within headspace. Mass and energy are also lost from the headspace via the venting. At each time interval, dt, a new temperature and pressure of the tank headspace is calculated to determine the net change in the heat and mass within the headspace. The calculation continues until an equilibrium temperature and pressure is reached where the mass and energy of the steam flow into the tank is equal to the mass and energy flow out the vent system.

Analysis starts with the following initial headspace conditions (IVFChapter 3-07). The initial headspace temperature, $\mathrm{T}_{\mathrm{hs}}$, is used as a reference for calculating the energy flow in and out of the tank.

$$
\begin{aligned}
\mathrm{T}_{\mathrm{hs}} & =150^{\circ} \mathrm{F} \\
\mathrm{P}_{\mathrm{HS}} & =14.7 \text { psia } \\
\mathrm{m}_{\mathrm{hs}} & =\mathrm{m}_{\text {air }}+\mathrm{m}_{\text {steam }} \\
& =7,1601 \mathrm{~b}_{\mathrm{m}}+01 \mathrm{~b}_{\mathrm{m}}
\end{aligned}
$$

The calculation process uses the conditions from previous step to calculate the new conditions in the following steps:

Step 1: Calculate the properties of the mixture of air and steam in the tank headspace for the present conditions.

$$
\begin{aligned}
& m_{\text {mix }}(t)=m_{a i r}(t)+m_{\text {steam }}(t) \\
& r h o_{\text {mix }}(t)=m_{\text {mix }}(t) / v o l_{\text {hs }} \\
& c p_{\text {mix }}(t)=\left[c p_{a i r} m_{a i r}(t)+c p_{\text {steam }} m_{\text {steam }}(t)\right] / m_{\text {mix }}(t) \\
& n_{\text {mix }}(t)=m_{\text {air }}(t) / m_{\text {air }}+m_{\text {steam }}(t) / m w_{\text {steam }}
\end{aligned}
$$

Step 2: Calculate the mass fraction of steam and air, $m f_{i}$ in the headspace. 


$$
\begin{aligned}
& m f_{\text {air }}(t)=m_{\text {air }}(t) / m_{\text {mix }}(t) \\
& m f_{\text {steam }}(t)=m_{\text {steam }}(t) / m_{\text {mix }}(t)
\end{aligned}
$$

Step 3: Calculate the flow of the headspace mixture out the vent paths.

$$
\text { flow } \text { vent }(t)=c_{v d}\left[\operatorname{press}(t) r h o_{\text {mix }}(t)\right]^{0.5}
$$

Step 4: Determine the mass of air and steam in the headspace for the next time interval.

$$
\begin{aligned}
m_{\text {air }}(t+d t)= & m_{a i r}(t)-\left[f \operatorname{low}_{\text {vent }}(t) r h o_{\text {mix }}(t) m f_{\text {air }}(t)\right] d t \\
m_{\text {steam }}(t+d t)= & m_{\text {steam }}(t)+\operatorname{mdot}_{\text {steam }} d t \\
& -\left[f \text { flow }_{\text {vent }}(t) r r_{\text {mix }}(t) m f_{\text {steam }}(t)\right] d t
\end{aligned}
$$

Step 5: Determine the new headspace temperature resulting from the addition of steam into the headspace and the lost of energy by the venting gas mixture. The energy in the system is referenced to the initial temperature in the headspace.

$$
\begin{aligned}
& q_{\text {vent }}(t)=\left(T_{h s}(t)-150^{\circ} F\right) f l o w_{\text {vent }}(t) r h o_{\text {mix }}(t) c p_{\text {mix }}(t) \\
& T_{h s}(t+d t)=T_{h s}(t)+\left[q_{\text {steam }}-q_{\text {vent }}(t)\right] d t /\left[m_{\text {mix }}(t) c p_{\text {mix }}(t)\right]
\end{aligned}
$$

Step 6: Finally the new pressure in the headspace using the ideal gas equation and the new headspace conditions:

$$
P_{h s}(t)=R_{\text {gas }} n_{\text {mix }}(t) T_{h s}(t) / v_{0} T_{h s}
$$

These six steps are repeated for each new time interval for the length of the transient.

\subsubsection{Analys is Results}

The analysis results (Appendix E) show that for assumed steam parameters and tank conditions, the tank headspace is pressurized. Table $C-1$ gives the temperature, pressure and flow rates predicted for this accident. There is sufficient pressure to challenge the ventilation filter HEPA filters.

After the HEPA filters fail, the steam flow into the tank is assumed to continue until the headspace is filled with steam and the temperature and pressure reach an equilibrium. At this condition, the mass and energy flow out the ventilation system matches the input flow by definition.

When the steam supply is finally shut-off upon the discovery of upset steam flow, the steam in the steam-filled headspace would begin to condenses to water. With the steam condensation, the pressure in the tank would decrease, potentially creating a negative pressure in the tank. However, because the length of time of the accident, the tanks walls and dome should be near the same temperature as the headspace gas at the end of the accident. Head loss from a passive tank by conduction through the covering soil is very slow allowing the headspace pressure easily remain equalized with the atmospheric pressure. 


\subsection{RADIOLOGICAL AND TOXICOLOGICAL SOURCE TERM}

To conservatively calculate the dose consequences from this accident scenario, the entire volume of contaminated air that was initially present in the headspace of a half-full tank $\left(V_{H S}=3.1 \times 10^{3} \mathrm{~m}^{3}\right.$ of air $)$ is assumed to be vented directly to the atmosphere without being filtered. This is a conservative value since analys is shows that 1 ess than $4 \%$ of the headspace air is vented prior to the assumed HEPA filter rupture. Subsequent releases from the headspace volume are assumed to be comprised of "clean" steam and are not quantified or considered in the dose calculation. The half-full tank scenario was conservatively chosen as the example used for this analys is because the accident consequence was more severe for this scenario than for a tank full of waste. The consequences calculated for the empty tank were similar to those for the half-full tank. The results of these analyses are included in the tables in Appendix F.

The partition fraction used to determine the amount of contamination in the headspace air is $1.0 \times 10^{-8}$. This is the value for agitated waste storage tanks under active ventilation and is based on information that has been published in RHO-RE-SA-216, Characterization of Airborne Radionuclide Particulates in Ventilated Liquid Waste Tanks. This is considered to be a conservative value since a major assumption in this analysis is that the tank is under passive ventilation, although this value would account for any material that may have been suspended from the waste transfer that occurred prior to the start of this accident scenario. From the same reference, a partition fraction of $1.0 \times 10^{-10}$ can be inferred for use with passively ventilated tanks.

Calculating the amount of respirable material released from the headspace air:

$V_{H S} \times$ (partition fraction) $=$ Amount of respirable material released

$$
\left(3.1 \times 10^{3} \mathrm{~m}^{3}\right)\left(1.0 \times 10^{-8}\right)=3.1 \times 10^{-5} \mathrm{~m}^{3}
$$

Converting to liters,

$$
\left(3.1 \times 10^{-5} \mathrm{~m}^{3}\right)\left(1,000 \mathrm{~L} / \mathrm{m}^{3}\right)=3.1 \times 10^{-2} \mathrm{~L}
$$

Additionally, since it is possible to pressurize the tank headspace to a point that would rupture contaminated HEPA filters present in the shutdown ventilation system, this quantity is added to the total released. For consistency between various analyses, the values for HEPA filter release amounts are taken from standard information that has been developed specifically for this FSAR effort (Van Vleet 1996).

The conservative release fraction used to determine the amount of waste released from the HEPA filter rupture is $1.0 \times 10^{-2}$. This value is based on information presented in DOE-HDBK-3010-94, Airborne Release Fractions/Rates and Respirable Fractions for Nonreactor Nuclear Facilities and is intended to be applied to HEPA filter media with no enclosure or for which the enclosure has been totally destroyed and the filter media widely scattered and impacted. This is not typically a foreseeable condition in this accident scenario. This value is considered to be conservative for this reason and the fact that the filter media would likely be at least moist (if not soggy) from being exposed 
to a sizeable steam flow (or very humid atmosphere), allowing less to be released in a rupture event.

The amount of respirable material released from the HEPA filter rupture:

$$
\begin{array}{cccc}
\text { Qla } & \text { DST } & 0.0009790 \mathrm{~L} & \begin{array}{c}
\text { (Appendix F) } \\
\text { Q1b }
\end{array} \text { AWF } \\
0.005618 \mathrm{~L} & \text { (Appendix F) }
\end{array}
$$

The resulting airborne source term in the accident scenario was determined by adding the fractions released from the vented headspace air and the HEPA filter rupture. This total is:

$$
\begin{gathered}
Q_{2 \mathrm{a}} \\
3.1 \times 10^{-2} \mathrm{~L}+9.79 \times 10^{-4} \mathrm{~L}=3.2 \times 10^{-2} \mathrm{~L}
\end{gathered}
$$

It is assumed that the airborne source term both entrained in the headspace and present on the HEPA filters is made up of DST liquids. All of the resulting airborne source term is conservatively assumed to be released in a short period time such that this is considered an acute release.

Appropriate dispersion coefficients and breathing rates are applied to develop the radiological consequences (Van Keuren 1996a).

Toxicological consequences are calculated using as a peak release, the total respirable amount of waste produced during venting of the headspace air and the HEPA filter rupture (i.e., $3.21 \times 10^{-2} \mathrm{~L}$ ). This ensures that toxicological consequences are developed conservatively for both the onsite and offsite receptor.

\subsection{CALCULATED RADIOLOGICAL DOSES}

The methodology that is used to calculate radiological dose consequences is documented in WHC-SD-WM-SARR-016, Rev. 2, Tank Waste Compositions and Atmospheric Dispersion Coefficients for use in ASA Consequence Assessments and WHC-SD-WM-SARR-037, Rev. 0, Development of Radiological Concentrations and Unit Liter Doses for TWRS FSAR Radiological Consequence Calculations.

\subsubsection{Input Data}

\section{Unit Liter Doses (ULDS)}

The ULDs for this analysis are taken from WHC-SD-WM-SARR-037, Rev. 0 , Development of Radiological Concentrations and Unit Liter Doses for TWRS FSAR Radiological Consequence Calculations.

$$
\begin{aligned}
U L D_{H} & =6.1 \times 10^{3} \mathrm{SV} / \mathrm{L} \text { (inhalation dose) } \\
U L D_{1} & =0.07 \mathrm{SV}-\mathrm{m}^{3} / \mathrm{s}-\mathrm{L} \text { (ingestion dose) }
\end{aligned}
$$

Dispersion Coefficients $\left(x / Q^{\prime} s\right)$

The onsite receptor is chosen to be at a distance of $100 \mathrm{~m}$ and the offsite receptor is chosen to be at a distance of $8,760 \mathrm{~m}$ to the North. The Methodology section of the TWRS FSAR contains additional details concerning the receptor locations. 


\section{HNF-SD-WM-CN-044 REV 2}

The following onsite and offsite $X / Q$ 's are from Van Keuren 1996a.

Onsite - The $X / Q^{1}$ for the acute release is $3.4 \times 10^{-2} \mathrm{~s} / \mathrm{m}^{3}$

The $X / Q^{\prime}$ for the 2-hour release is $1.13 \times 10^{-2} \mathrm{~s} / \mathrm{m}^{3}$

The $x / Q^{\prime}$ for the chronic release is $4.03 \times 10^{-4} \mathrm{~s} / \mathrm{m}^{3}$

Offsite - The $X / Q^{\prime}$ for the acute release is $2.8 \times 10^{-5} \mathrm{~s} / \mathrm{m}^{3}$

The $x / Q^{\prime}$ for the 2-hour release is $2.12 \times 10^{-5} \mathrm{~s} / \mathrm{m}^{3}$

The $X / Q^{1}$ for the chronic release is $1.24 \times 10^{-7} \mathrm{~s} / \mathrm{m}^{3}$

The $x / Q^{\prime}$ values for releases greater than 2 hours but less than 1 year ( 8760 hrs) are determined using logarithmic interpolation.

$$
\frac{\log \left(\frac{\chi}{Q}\right)_{2-h x}-\log \left(\frac{\chi}{Q}\right)_{x-h x}}{\log \left(\frac{\chi}{Q}\right)_{2-h x}-\log \left(\frac{\chi}{Q}\right)_{8760-h x}}=\frac{\log (2)-\log (x)}{\log (2)-\log (8760)}
$$

Thus, for $x$ equal to some time greater than 2 hours but less than 8760 hrs, the equation can be solved for the $\left(x / Q^{\prime}\right)_{\chi-h r}$. This value is what is used in the calculation. See Appendix $F$ for the time periods and interpolated $x / Q^{\prime}$ values.

Breathing Rate (BR)

$3.3 \times 10^{-4} \mathrm{~m}^{3} / \mathrm{s}$ light activity breathing rate is used to calculate consequences to both the onsite and offsite receptors (Van Keuren 1996a).

Amount of Material Released (Q)

$$
Q=3.2 \times 10^{-2} \mathrm{~L} \text {. }
$$

Using the formula presented on page 4-4 of Van Keuren (1996a) and modifications for a 24 hour ingestion dose to the offsite receptor from cowley et a1. (1996), the radiological dose consequences can be calculated.

\subsubsection{Calculations}

Onsite Consequences:

$$
D(S v)=Q(L) \times \frac{X}{Q^{\prime}}\left(\mathrm{s} / \mathrm{m}^{3}\right) \times R\left[\mathrm{~m}^{3} / \mathrm{s}\right] \times \mathrm{ULD}_{\mathrm{H}}[\mathrm{Sv} / \mathrm{L}]
$$

Inhalation Dose:

$D(S v)=\left(3.2 \times 10^{-2} \mathrm{~L}\right)\left(7.51 \times 10^{-3} \mathrm{~s} / \mathrm{m}^{3}\right)\left(3.3 \times 10^{-4} \mathrm{~m}^{3} / \mathrm{s}\right)\left(6.1 \times 10^{3} \mathrm{~Sv} / \mathrm{L}\right)$

$D(S v)=4.838 \times 10^{-4} \mathrm{~Sv}$ 
Offsite Consequences:

$$
D(S V)=Q(L) \times \frac{X}{Q^{\prime}}\left(s / m^{3}\right) \times\left(\left(R\left[m^{3} / s\right] \times U L D_{H}[S V / L]\right)+U L D_{I}\left[S V-m^{3} / s-L\right]\right)
$$

$\begin{aligned} D(\mathrm{~Sv})= & \left(3.2 \times 10^{-2} \mathrm{~L}\right)\left(1.13 \times 10^{-5} \mathrm{~s} / \mathrm{m}^{3}\right)\left[\left(3.3 \times 10^{-4} \mathrm{~m}^{3} / \mathrm{s}\right)\left(6.1 \times 10^{3} \mathrm{~Sv} / \mathrm{L}\right)+\right. \\ & \left.0.068 \mathrm{~Sv}-\mathrm{m}^{3} / \mathrm{s}-\mathrm{L}\right]\end{aligned}$

$D(S v)=7.279 \times 10^{-7} \mathrm{~Sv}$

\subsection{CALCULATED TOXICOLOGICAL DOSES}

The methodology that is used to calculate toxicological exposure consequences is documented in WHC-SD-WM-SARR-011, Rev. 2, Toxic Chemical Considerations for Tank Farm Releases.

\subsubsection{Input Data}

The probability of this unmitigated accident scenario is anticipated (see Section 1.2) and the waste has the same constituents as DST 1iquids (Van Keuren [1996b]). The worst constituents, toxicologically, reported in the preceding reference include corrosives and irritants such as ammonia and tributyl phosphate. This event is a puff-type release to both the onsite and offsite receptors. Sum-of-fraction values are extracted from Van Keuren (1996b) to determine the toxicological consequences.

\section{Sum-of-Fraction Values from Van Keuren (1996b)}

The sum-of-fraction value for the onsite receptor is $1.0 \times 10^{4} \mathrm{~s} / \mathrm{L}$ (DST liquids) $/ 2.6 \mathrm{~s} / \mathrm{m}^{3}$ (DST vapor space).

The sum-of-fraction value for the offsite receptor is $8.4 \mathrm{~s} / \mathrm{L}$ (DST liquids) $/ 2.3 \times 10^{-3} \mathrm{~s} / \mathrm{m}^{3}$ (DST vapor space).

\section{Quantity Released}

The quantity of material released was calculated previously to be a total of $3.2 \times 10^{-2} \mathrm{~L}$.

\subsubsection{Calculations}

By directly multiplying the sum-of-fraction value by the waste release rate divided by the time it takes to vent $95 \%$ of the headspace gases to the atmosphere, the toxicological consequences can be calculated for both the onsite and offsite receptors. The following are for the average flow rate example. The results of the maximum flow rate are included in Appendix $F$.

HEPA filter consequence for the half-full tank:

$$
\begin{aligned}
& \text { Onsite }-\quad \text { Calculation: }\left[9.79 \times 10^{-4} \mathrm{~L} /(335 \mathrm{~min} \times 60 \mathrm{~s} / \mathrm{min})\right](1.0 \times \\
& \left.10^{4} / \mathrm{L}\right)=4.87 \times 10^{-4} . \\
& \text { Offsite }- \\
& \begin{array}{l}
\text { Calculation: }\left[9.79 \times 10^{-4} \mathrm{~L} /(335 \mathrm{~min} \times 60 \mathrm{~s} / \mathrm{min})\right](8.4 \mathrm{~L}) \\
=4.1 \times 10^{-7} .
\end{array}
\end{aligned}
$$


Headspace release consequence for the half-full tank:

$$
\begin{array}{ll}
\text { Onsite - } & \text { Calculation: }\left[3.116 \times 10^{-2} \mathrm{~L} /(335 \mathrm{~min} \times 60 \mathrm{~s} / \mathrm{min})\right] \\
& \left(1.0 \times 10^{4} \mathrm{~s} / \mathrm{L}\right)=1.6 \times 10^{-2} \mathrm{~s} \\
\text { Offsite - } & \text { Calculation: }\left(3.116 \times 10^{-2} \mathrm{~L} / 335 \mathrm{~min} \times 60 \mathrm{~s} / \mathrm{min}\right)(8.4 \mathrm{~s} / \mathrm{L}) \\
& =1.302 \times 10^{-5} .
\end{array}
$$

Gas release consequence for the half-full tank:

$$
\begin{aligned}
\text { Onsite - } & \text { Calculation: }\left(3.1 \times 10^{3} \mathrm{~m}^{3} / 335 \mathrm{~min} \times 60 \mathrm{~s} / \mathrm{min}\right)\left(2.6 \mathrm{~s} / \mathrm{m}^{3}\right) \\
& =4.01 \times 10^{-1} \\
\text { Offsite - } & \text { Calculation: }\left(3.1 \times 10^{3} \mathrm{~m}^{3} / 335 \mathrm{~min} \times 60 \mathrm{~s} / \mathrm{min}\right) \\
& \left(2.3 \times 10^{-3} \mathrm{~s} / \mathrm{m}^{3}\right)=3.54 \times 10^{-4}
\end{aligned}
$$

\subsection{RESULTS}

\subsubsection{Radiological}

The onsite radiological dose consequence value $\left(4.9 \times 10^{-4} \mathrm{~Sv}\right)$ is shown to be below the risk guidelines for an anticipated accident $\left(5.0 \times 10^{-3} \mathrm{SV}\right)$ as provided in WHC-CM-4-46, Rev. 1.

The offsite radiological dose consequence value $\left(7.6 \times 10^{-7} \mathrm{~Sv}\right)$ is shown to be below the risk guidelines for an anticipated accident $\left(1 \times 10^{-3} \mathrm{~Sv}\right.$ ) as provided in WHC-CM-4-46, Rev. 1.

\subsubsection{Toxicological}

As a result of this accident the exposure to the onsite receptor is calculated to be $4.2 \times 10^{-1}$ as a fraction of the risk guidelines. Similarly, the exposure to the offsite receptor is calculated to be $3.7 \times 10^{-4}$, as a fraction of the risk guidelines. The values for both the onsite and offsite receptors are below the risk guidelines $(<1)$. Even when the maximum flow rate is used, the onsite exposure is $9.1 \times 10^{-1}$ as a function of the risk guidelines.

\subsection{CONCLUSIONS}

Analysis of this accident scenario shows that a pressurization of the tank headspace is possible which could result in a total release of the headspace contents along with the contents of ruptured HEPA filters.

The radiological dose consequences for the both the onsite and offsite receptors are below the risk guidelines (Tables in Appendix F).

The toxicological exposure consequences show that the values for both the onsite and offsite receptors are below the risk guidelines (Tables in Appendix F).

Table 1.9-1 is a summary of the accident consequences as developed in the calculation note for a double-shell tank with average flow. Other consequences are calculated in a similar fashion and are presented in Appendix $\mathrm{F}$. 
Table 1.9-1. Summary of Accident Consequences

\begin{tabular}{||c|c|c|c|c||}
\hline \multirow{2}{*}{ Accident } & \multicolumn{4}{|c||}{ Consequenses } \\
\cline { 2 - 5 } & Radiological (Sv) & \multicolumn{2}{|c|}{ Toxicological } \\
\cline { 2 - 5 } & Onsite & offsite & Onsite & Offsite \\
\hline $\begin{array}{c}\text { Steam intrusion } \\
\text { from interfacing } \\
\text { facilities }\end{array}$ & $4.9 \times 10^{-4}$ & $7.6 \times 10^{-7}$ & $4.2 \times 10^{-1}$ & $3.7 \times 10^{-4}$ \\
\hline \hline
\end{tabular}

\subsection{REFERENCES}

Cowley, W. L., 1996, Development of Radiological Concentrations and Unit Liter Doses for TWRS FSAR Radiological Consequence Calculations, WHC-SD-WM-SARR-037, Rev. 0, Westinghouse Hanford Company, Rich Tand, Washington.

Kimura and Lindsey, 1987, Characterization of Airborne Radionuclide Particulates in Ventilated Liquid Waste Tanks, Rockwell Hanford Operations, Richland, Washington.

Marusich, R. M., 1996, WHC-SD-WM-CN-051, Rev. 0, The Effects of Load Drop, Uniform Load and Concentrated Loads on Waste Tanks, Westinghouse Hanford Company, Richland, Washington.

Van Keuren, J. C., 1996a, WHC-SD-WM-SARR-016, Rev. 2, Tank Waste Compositions and Atmospheric Dispersion Coefficients for use in ASA Consequence Assessments, Westinghouse Hanford Company, Richland, Washington.

Van Keuren, J. C., 1996b, WHC-SD-WM-SARR-011, Rev. 2, Toxicological Chemical Considerations for Tank Farm Releases, Westinghouse Hanford Company, Richland, Washington.

Van Vleet, R. J., 1996, Waste Tank Ventilation System Waste Material Accumulations, WHC-SD-WM-CN-054, Rev. 0, Westinghouse Hanford Company, Richland, Washington.

WHC, 1991, Safety Analysis Manual, WHC-CM-4-46, Section 4.0, Rev. 1, November 15, 1991, Westinghouse Hanford Company, Richland, Washington. 
HNF-SD-WM-CN-044 REV 2

\section{APPENDIX A}

INFORMATION VALIDATION FORMS

A-1 
HNF-SD-WM-CN-044 REV 2

This page intentionally left blank. 
HNF-SD-WM-CN-044 REV 2

Information Validation fora

Tracking $;$ IVF-Chaoter 3-07

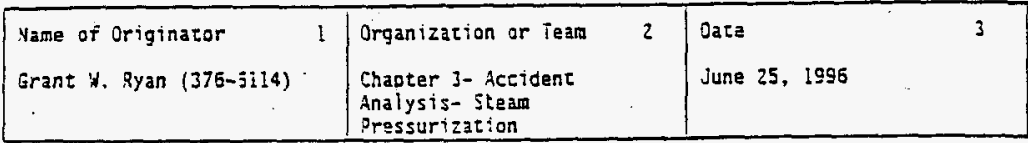


Statement of Prodien

ACCIDEIT SCBAARIO JESCRIPTION

A liquid wasta transiar to aither a doublesinell tank or OCRT is initiaced from a facjlity (e.g., 24Z-A Evaoorator, 244-AR Vault, or $Z$ Plant) using a stean jet ds the motive force to move the liquid. After the waste has been transierred, the staam jet is not shut off and pure saean is routsd to headspaca of the recsiving iank.

In the scenario analyzed, 00 psig saturated stean is exhausted into the headspaca of a full doubie-snell tank at a Fow rate of $2,400 \mathrm{lb} / \mathrm{hr}$. The radiological and toxicological dose consequencas, if any, associated with the accident scanario are to be calculated.

i. Calculations will also be periormed to detemine if a vacuum can be orawn on the double-shell tank artar the steam has been shut-off and the steam filled atmosphere condenses to water conoletely.

\section{ASSUMPTIONS USE FOR PRESSURIZATION PORTION OF SCZVARIO}

1. The saturated staam is introducad into a full double-shell tank with available headspace nocelled is a hemisphers with a radius of $37.5 \mathrm{Ft}$. This is considered a canservative seometry sincs it sligintly overostimates the availabie siaam exdansion roiume.

2. Headspace dir temperacure is initially at $150^{\circ} \mathrm{F}$.

3. Headspace pressure initialiy at 14.7 psia.

4. Tank is under passive ventilation during wastz transfar (i.z., no active ventilation).

5. Sazurated stean flow rate incroduc ad into the tank headsoace is 2,400 lbm/hr. This is the flow race dssociated with a stamm jet transter from 244-aR lault to the tank farms and is consicered to bound steam jet transtars from z-?lant (PFP), 222-5 Laoorztory, 242-4 Evadorator, PUREX, and i-?lant. These are alt the known iocations where staar may acsess the ianks (both doubie-shell and ockTs).

5. Saturated staam pressure is 90 psigg ( -105 psia).

7. Saturated steam is injectad into the headspace (not into the wasta.)

ASSUMPTIONS USE] FOR YACIUM PORTION OF SCEARIO

1. The tank wall tenoerature is assumed to be constant at $50^{\circ} \mathrm{F}$. This value is lower than the headspace air temperature (i.e., 150\% $\mathrm{F}$ ) assumed in the pressurization portion of the accident scanario to ensure that the situation is aodelled conservatively.

EXPLICITLY concur with or deny (by including appropriate documentation) the assumption made above.

REFERENES

N/A 


\section{Intormation Validation form}

Tracking

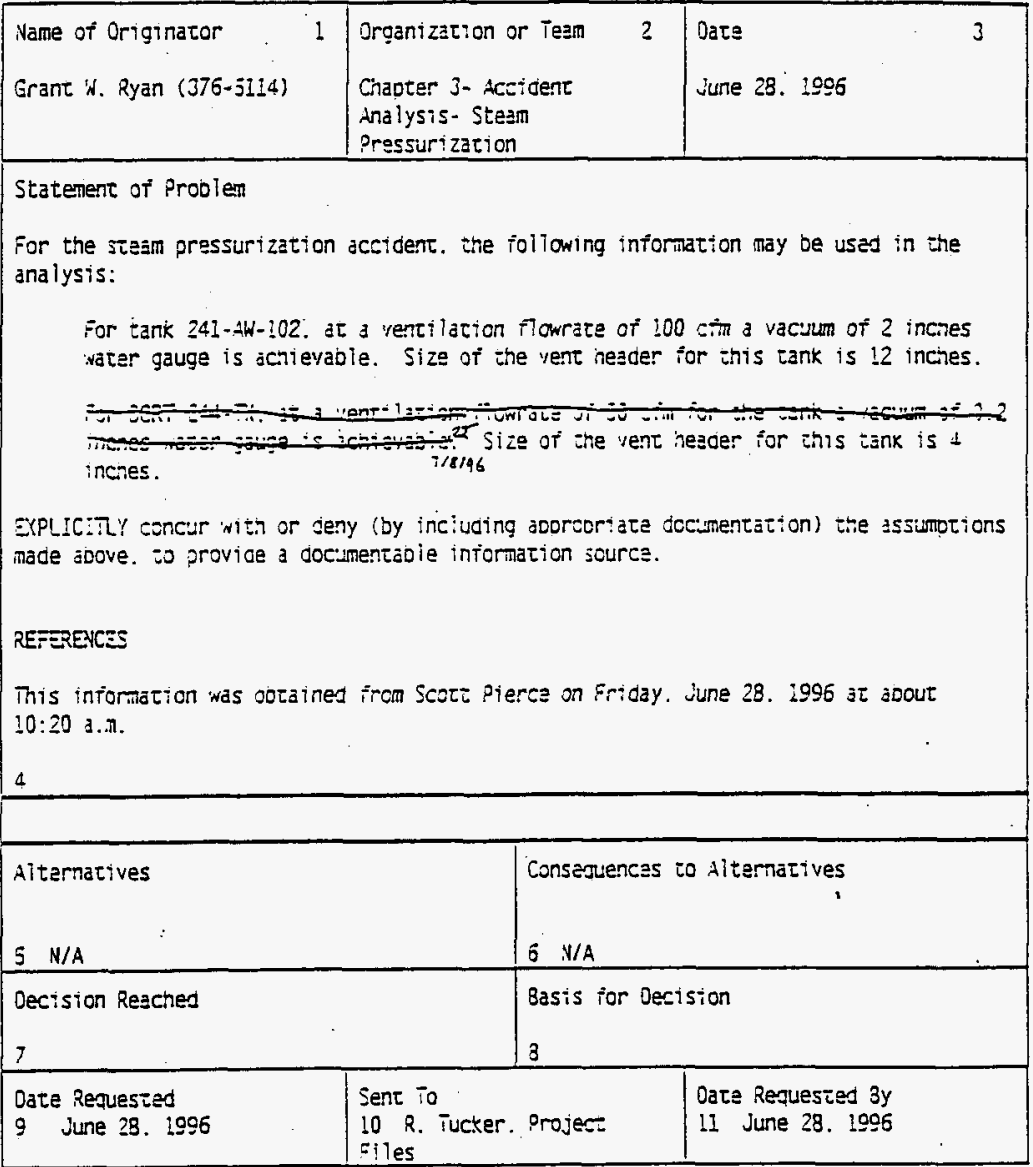

BES MWPOE COW 
HNF-SD-WM-CN-044 REV 2

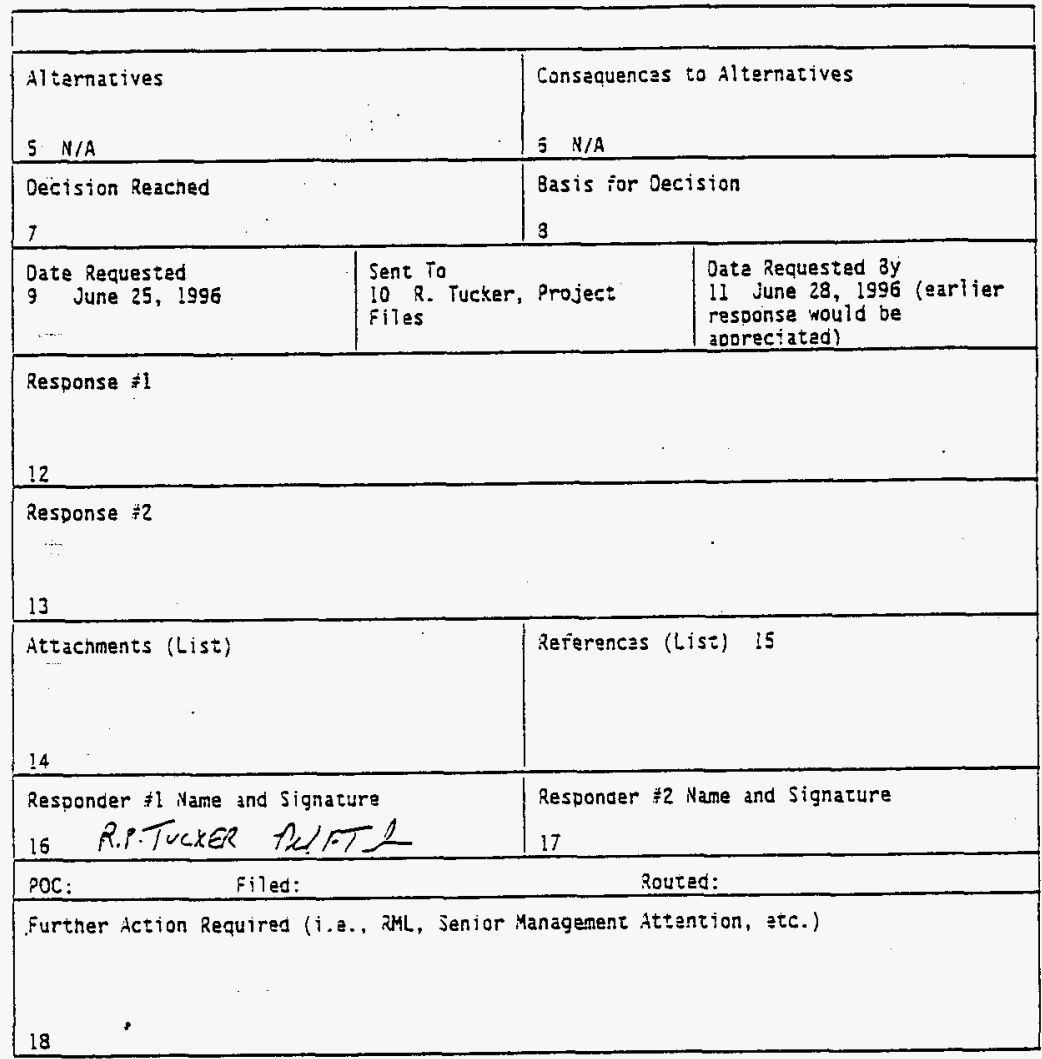




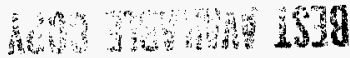

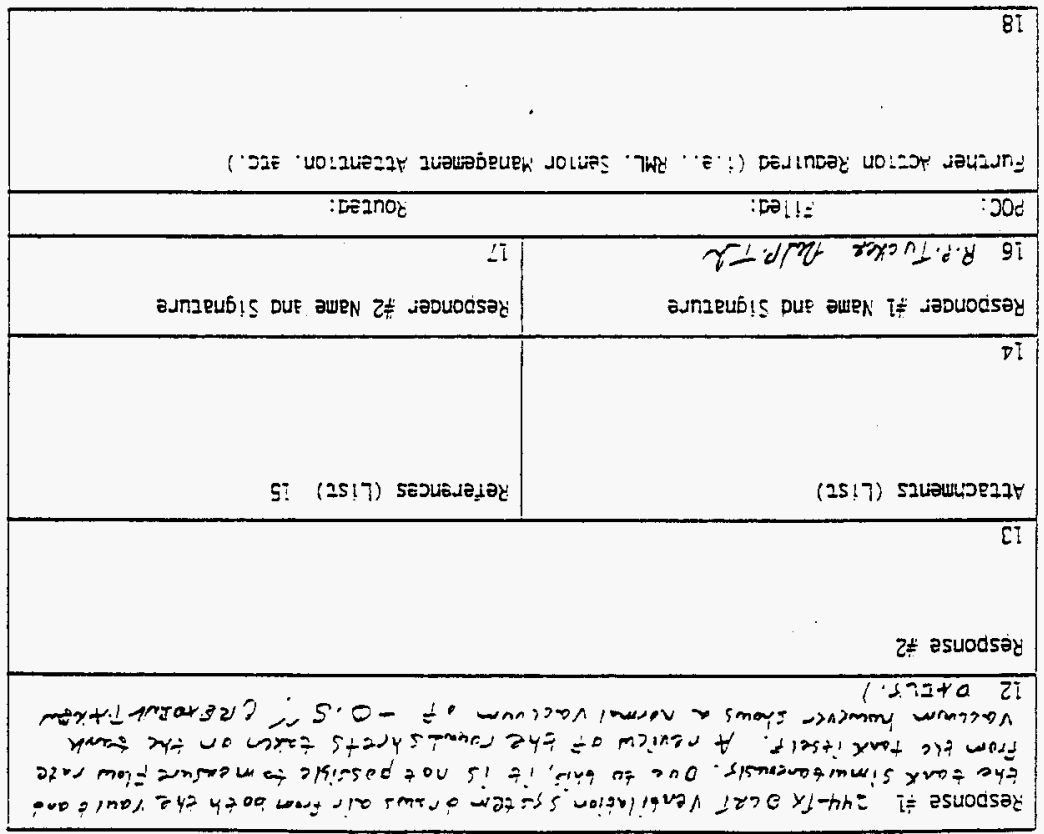


HNF-SD-WM-CN-044 REV 2

This page intentionally left blank.

A- 8 
HNF-SD-WM-CN-044 REV 2

\begin{abstract}
APPENDIX B
HAZARD ANALYSIS RESULTS FOR INTERFACING FACILITIES THAT USE STEAM JETS
\end{abstract}


HNF-SD-WM-CN-044 REV 2

This page intentionally left blank. 
Table B-1. Hazard Analysis Results for Interfacing Facilities That Use Steam Jets (2 sheets).

\begin{tabular}{|c|c|c|c|}
\hline ID & Hazardous Condition & Cause & $\begin{array}{l}\text { Rep } \\
\text { Acc }\end{array}$ \\
\hline $\begin{array}{l}I-242 A-6-C M \\
P-A\end{array}$ & $\begin{array}{l}\text { Release (steam) of aerosols to } \\
\text { the atmosphere through unsealed } \\
\text { cracks in the cover blocks due } \\
\text { to over pressurization of the } \\
\text { receiver tank. }\end{array}$ & $\begin{array}{l}\text { Human error - Steam } \\
\text { block valve } \\
\text { inadvertently left } \\
\text { opened. }\end{array}$ & 32 \\
\hline $\begin{array}{l}\mathrm{I}-242 \mathrm{~A}-2-\mathrm{CM} \\
\mathrm{P}-\mathrm{B}\end{array}$ & $\begin{array}{l}\text { Release to the atmosphere } \\
\text { through unsealed cracks in the } \\
\text { cover blocks due to over } \\
\text { pressurization of the receiver } \\
\text { tank. }\end{array}$ & $\begin{array}{l}\text { Steam block valves } \\
\text { inadvertently opened or } \\
\text { left open }\end{array}$ & $32 x$ \\
\hline $\begin{array}{l}I-222 S-1-L V \\
L-A\end{array}$ & $\begin{array}{l}\text { Release (steam) of aerosols and } \\
\text { entrained particulates to } \\
\text { atmosphere through ventilation } \\
\text { due to over pressurization of } \\
244-S-D C R T \text { caused by sending } \\
\text { just steam to tank farm. }\end{array}$ & $\begin{array}{l}\text { Human Error - Failing } \\
\text { to shut off steam after } \\
\text { TK-102 is empty }\end{array}$ & $32 X$ \\
\hline $\begin{array}{l}I-222 S-2-P R \\
S-A\end{array}$ & $\begin{array}{l}\text { Release (steam) of aerosols and } \\
\text { particulates to atmosphere } \\
\text { through ventilation due to over } \\
\text { pressurization of } 244-5 \text { DCRT } \\
\text { caused by sending just steam to } \\
\text { tank farm. }\end{array}$ & $\begin{array}{l}\text { Steam reducer valve } \\
\text { fails open. }\end{array}$ & $32 X$ \\
\hline $\begin{array}{l}\text { I-PUREX-1-L } \\
\text { VL-A }\end{array}$ & $\begin{array}{l}\text { Release of aerosols from 105AW } \\
\text { through cracks in the cover } \\
\text { block due to pressurizing } 105 \mathrm{AW} \\
\text { from transfer of steam. }\end{array}$ & $\begin{array}{l}\text { Human Error - Failure } \\
\text { to shut off steam jet } \\
\text { when } U-3 \text { is empty. }\end{array}$ & $32 x$ \\
\hline $\begin{array}{l}\text { I-PUREX-3-L } \\
\text { VL-A }\end{array}$ & $\begin{array}{l}\text { Release of aerosols from } 105 \mathrm{AW} \\
\text { through cracks in the cover } \\
\text { block due to pressurizing 105AW } \\
\text { from transfer of steam. }\end{array}$ & $\begin{array}{l}\text { Human Error - Failure } \\
\text { to shut off steam jet } \\
\text { when } U-3 \text { is empty. }\end{array}$ & $32 X$ \\
\hline $\begin{array}{l}\text { I-TPLANT-2- } \\
\text { CMP-A }\end{array}$ & $\begin{array}{l}\text { Release (steam) of aerosols and } \\
\text { entrained particulates to } \\
\text { atmosphere through ventilation } \\
\text { due to over pressurization of } \\
244-S-D C R T \text { caused by sending } \\
\text { just steam to tank farm. }\end{array}$ & $\begin{array}{l}\text { Human Error - Steam } \\
\text { block valve } \\
\text { inadvertently opened or } \\
\text { failure to close valve } \\
\text { when tank 15-1 is low }\end{array}$ & $32 x$ \\
\hline $\begin{array}{l}\text { XS-02-FLOWO } \\
2\end{array}$ & $\begin{array}{l}\text { Release of aerosols and } \\
\text { particulate from DCRT } \\
\text { ventilation filter due to } \\
\text { transfer of steam from PFP steam } \\
\text { jet into DCRT headspace }\end{array}$ & $\begin{array}{l}\text { Human error (failure to } \\
\text { shut off steam jet at } \\
\text { completion of transfer) } \\
\text { which causes DCRT } \\
\text { ventilation filter } \\
\text { failure }\end{array}$ & $32 X$ \\
\hline
\end{tabular}


Table B-1. Hazard Analysis Results for Interfacing Facilities That Use Steam Jets (2 sheets).

\begin{tabular}{|c|c|c|c|}
\hline ID & Hazardous Condition & Cause & $\begin{array}{l}\text { Rep } \\
\text { Acc }\end{array}$ \\
\hline $\begin{array}{l}\text { I-PFP-2-TMP } \\
-B\end{array}$ & $\begin{array}{l}\text { Release (steam) of aerosols and } \\
\text { entrained particulate from } \\
244-T X \text { ventilation system due to } \\
\text { saturating HEPAs with steam due } \\
\text { to failure of steam reducer } \\
\text { which sends higher pressure } \\
\text { steam to steam jet, gassing it } \\
\text { out and sends steam to } 244-T X \text {. }\end{array}$ & $\begin{array}{l}\text { Failure of steam } \\
\text { reducer }\end{array}$ & $32 x$ \\
\hline $\begin{array}{l}\text { I-PUREX-2-P } \\
\text { RS-A }\end{array}$ & $\begin{array}{l}\text { Release (steam) of aerosols and } \\
\text { particulates through cracks in } \\
\text { the cover block from the } \\
\text { receiver tank due to tank } \\
\text { pressurization from sending } \\
\text { steam caused by steam reducer } \\
\text { failure which gasses out the } \\
\text { steam jet and sends just steam. }\end{array}$ & Steam Reducer fails & $32 X$ \\
\hline $\begin{array}{l}\text { I-PUREX-4-P } \\
\text { RS-A }\end{array}$ & $\begin{array}{l}\text { Release of aerosols and } \\
\text { particulates through cracks in } \\
\text { the cover block from the } \\
\text { receiver tank due to tank } \\
\text { pressurization from sending } \\
\text { steam caused by steam reducer } \\
\text { failure which gasses out the } \\
\text { steam jet and sends just steam. }\end{array}$ & Steam Reducer fails & $32 X$ \\
\hline $\begin{array}{l}\text { XS-03-PRESO } \\
5\end{array}$ & $\begin{array}{l}\text { Release of toxic vapors from } \\
\text { DCRT due to increased } \\
\text { concentrations in DCRT } \\
\text { atmosphere }\end{array}$ & $\begin{array}{l}\text { Transfer of steam from } \\
\text { PFP causing evolution } \\
\text { of toxic gases due to } \\
\text { heating tank }\end{array}$ & $32 X$ \\
\hline
\end{tabular}


HNF-SD-WM-CN-044 REV 2

APPENDIX C

WASTE TANK HEADSPACE GAS VENT FLON DURATION

C-1 
HNF-SD-WM-CN-044 REV 2

This page intentionally left blank. 


\begin{tabular}{||l|l|l|l|l||}
\hline \multicolumn{3}{|c|}{ Table C-1. Waste Tank Headspace Gas Vent Flow Duration } \\
\hline Case & $\begin{array}{l}\text { Maximum } \\
\text { Headspace } \\
\text { Pressure }\end{array}$ & $\begin{array}{l}\text { Maximum } \\
\text { Headspace } \\
\text { Temperature }\end{array}$ & $\begin{array}{l}\text { Maximum } \\
\text { Headspace } \\
\text { Gas Flow } \\
\text { (15 minute } \\
\text { average) }\end{array}$ & $\begin{array}{l}\text { Time to Vent } \\
\text { 95\% of the } \\
\text { original } \\
\text { headspace } \\
\text { gas }\end{array}$ \\
\cline { 2 - 5 } & psia & F & ft ${ }^{3} /$ min & min \\
\hline Nominal & 3.3 & 292 & 732 & 335 \\
\hline $\begin{array}{l}\text { Increased steam } \\
\text { temperature from } \\
\text { 90 F to 225 F }\end{array}$ & 3.5 & 319 & 751 & 325 \\
\hline $\begin{array}{l}\text { Double steam flow } \\
\text { from 0.677 1b/sec } \\
\text { to 1.333 ib/sec }\end{array}$ & 7.2 & 293 & 974 & 197 \\
\hline $\begin{array}{l}\text { Increase in } \\
\text { headspace volume } \\
\text { equivalent to } \\
\text { tank with 10 in. } \\
\text { waste. }\end{array}$ & 3.3 & 292 & 733 & 560 \\
\hline $\begin{array}{l}\text { Decrease in } \\
\text { headspace volume } \\
\text { equivalent to } \\
\text { tank with 410 in. } \\
\text { waste. }\end{array}$ & 3.3 & 292 & 703 & 113 \\
\hline $\begin{array}{l}\text { Double the outlet } \\
\text { flow resistance }\end{array}$ & 7.2 & 292 & 491 & 391 \\
\hline $\begin{array}{l}\text { Half the outlet } \\
\text { flow resistance }\end{array}$ & 1.2 & 291 & 981 & 305 \\
\hline
\end{tabular}


HNF-SD-WM-CN-044 REV 2

This page intentionally left blank.

C -4 
HNF-SD-WM-CN-044 REV 2

\section{APPENDIX D}

PARTITION FRACTION DISCUSSION AND HEPA FILTER RELEASE AMOUNTS 
HNF-SD-WM-CN-044 REV 2

This page intentionally left blank. 


\section{Development of Headspace Partition Fraction}

Radioactive material is carried from the tank waste material into the tank headspace atmosphere through several physical processes. Only a fraction (the partition fraction) of the waste constituents in a tank will migrate to the headspace atmosphere. The partition fraction is the ratio of tank headspace radioactivity concentration to the concentration in that tank's solid or liquid waste, whichever is used as the basis.

Kimura and Lindsey (1987) report on the ratio of activity concentration in tank headspace samples to activity concentration in tank liquid waste material samples taken from DSTs during ALC operation, during waste transfer operations, and during static conditions. The characterization effort focused on cesium because it is prevalent in nearly all of the tank waste analyzed, producing the largest numbers, and is therefore considered bounding. The sample analyses indicated the following: - ALC operations - Observed ${ }^{137} \mathrm{Cs}$ partition fractions ranged from $1.02 \times$
$10^{-9}$ to $2.49 \times 10^{-9}$

- Tank waste transfer operations - observed ${ }^{137} \mathrm{Cs}$ partition fractions ranged from $1.02 \times 10^{-12}$ to $5.25 \times 10^{-10}$

- Static tank waste conditions - observed ${ }^{137} \mathrm{Cs}$ partition fractions ranged from about $1.00 \times 10^{-13}$ to $6.9 \times 10^{-11}$.

The results indicate the partition fraction for DST and AWF tanks during operations that result in worst-case liquid waste agitation conditions would be bounded by a partition fraction of $10^{-8}$, which is the number used in this accident analysis.

For an unagitated tank liquid waste scenario (i.e., long-term passive ventilation), static waste conditions, the above information indicates a partition fraction of about $1 \times$ $10^{-10}$.

\section{References}

Kimura and Lindsey, 1987, Characterization of Airborne Radionuclide Particulates in Ventilated Liquid Waste Tanks, Rockwell Hanford 0perations, Richland, Washington. 
HNF-SD-WM-CN-044 REV 2

This page intentionally left blank.

D-4 
HNF-SD-WM-CN-044 REV 2

APPENDIX E

CALCULATION NOTES FOR STEAM INTRUSION

E-1 
HNF-SD-WM-CN-044 REV 2

This page intentionally left blank. 


\section{Calculation Notes for Steam Intrusion}

Ralph Crowe

Safety Analysis and Risk Assessment

Specialty Engineering

Fluor Daniel Nortwest, Inc.

References

Cengel, Y. A. and M.A. Boles, 1994, Thermodynamics, An Engineering Approach, 2nd Edition, McGraw Hill Publishing, Inc. New York, New York.

Crane, 1985, Flow of Fluids Through Valves, Fittings and Pipe, Crane Co. New York, New York.

Holman, J. P., 1990, Heat Transfer, 7th. Edition, McGraw Hill Publishing Inc, New York, New York.

MathSoft, 1995, MathCad Plus 6.0, User's Guide, Mathsoft Inc., Cambridge, Massachuetts.

This report was written in MathCad Plus 6.0 Professional Edition (Maftsoft 1995). The following constants and equations were used as a part of the calculation.

Constants

$$
\rho_{\text {gas }}(P, T, M)\left(\begin{array}{c}
P \cdot M \\
R_{\text {gas }} \mathrm{T}
\end{array}\right)
$$

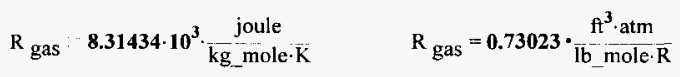

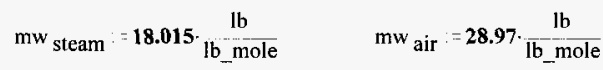

Steam Flow into tank, (IVF Chapter 3-07)

$$
\begin{aligned}
& \mathrm{P}_{\text {steam }}-\mathbf{1 0 5} \cdot \mathrm{psi} \quad \mathrm{T}_{\text {steam }}-\mathbf{3 3 1 . 7 \cdot \mathrm { F }} \mathrm{h}_{\text {steam }} \mathbf{1 1 8 8 . 8}_{\mathrm{lb}}^{\mathrm{BTU}} \\
& \mathrm{T}_{\text {atm }}-150 \cdot \mathrm{F} \quad \mathrm{h}_{\text {atm }}: \mathbf{1 1 2 6 . 1} \cdot \frac{\mathrm{BTU}}{\mathrm{l}} \mathrm{lb}
\end{aligned}
$$

\footnotetext{
Mass and energy

flow into tank,

$$
\text { steam_flow :- } 0.667 \cdot \frac{\mathrm{lb}}{\mathrm{sec}} \quad \text { steam_flow }=0.303 \cdot \frac{\mathrm{kg}}{\mathrm{sec}}
$$
}

(IVF Chapter 3-07)

$$
\text { heat_in : }=\left(\mathrm{h}_{\text {steam }}-\mathrm{h}_{\mathrm{atm}}\right) \cdot \text { steam_flow } \quad \text { heat_in }_{-}=\mathbf{4 1 . 8} \cdot \frac{\mathrm{BTU}}{\mathrm{sec}} \quad \text { heat_in }=\mathbf{4 4 . 1} \cdot \mathrm{kW}
$$

Time to heat $560 \mathrm{ft}$ of schedule 4010 " pipe

$$
\begin{aligned}
& \text { Weight of pipe per foot, } \quad w_{\text {pipe }}:=40.48 \cdot \frac{\mathrm{lb}}{\mathrm{ft}} \\
& \text { (Crane page } \mathrm{B}-17 \text { ) }
\end{aligned}
$$

Specific heat of pipe, cp pipe $:=0.11 \cdot \frac{\mathrm{BTU}}{\mathrm{Ib} \cdot \mathrm{F}}$

Heat of vaporization at

$240 \mathrm{~F}$ (Crane)

$$
h_{f g}:=950 \cdot \frac{B T U}{1 b}
$$

$$
\underbrace{\left(\mathrm{w}_{\text {pipe }}\right) \cdot(560 \cdot \mathrm{ft}) \cdot\left(\mathrm{cp}_{\text {pipe }}\right)}_{\text {steam_flow } \cdot h_{\mathrm{fg}}} \cdot\left(\mathrm{T}_{\text {steam }}-\mathrm{T}_{\text {atm }}\right)=\mathbf{1 1 . 9} \cdot \mathrm{min}
$$


Initial tank conditions

$$
\begin{array}{rc}
\mathrm{P}_{\text {air }}:=\mathbf{1} \cdot \mathrm{atm} & \mathrm{T}_{\text {air }}:=\mathbf{1 5 0} \cdot \mathrm{F}+460 \cdot \mathrm{R} \\
\mathrm{P}_{\text {air }}=\mathbf{1 0 1 . 3} \cdot \mathrm{kPa} & \mathrm{T}_{\text {air }}=\mathbf{3 3 8 . 9} \cdot \mathrm{K} \\
\rho_{\text {air }}:=\rho_{\text {gas }}\left(\mathrm{P}_{\text {air }}, \mathrm{T}_{\text {air }}, \mathrm{mw}_{\text {air }}\right) & \rho_{\text {air }}=\mathbf{0 . 0 6 5} \cdot \frac{\mathrm{lb}}{\mathrm{ft}^{3}} \quad \rho_{\text {air }}=1.042 \cdot \frac{\mathrm{kg}}{\mathrm{m}^{3}}
\end{array}
$$

Headspace volume head_space $($ waste_depth $):=187976 \cdot \mathrm{ft}^{3}$ - waste_depth.2750 $\frac{\text { gal }}{\text { in }}$

$$
\text { hsv : = head_space }(212 \cdot \mathrm{in}) \quad \text { hsv }=1.10 \cdot 10^{5} \cdot \mathrm{ft}^{3} \quad \text { hsv }=3.1 \cdot 10^{3} \cdot \mathrm{m}^{3}
$$

\section{Vent modeling}

normal vent flow conditions $\quad \mathrm{Q}:=\mathbf{1 0 0} \cdot \frac{\mathrm{ft}^{3}}{\mathrm{~min}} \quad \Delta \mathrm{P}:=\mathbf{2} \cdot$ in_H$_{-} \mathrm{H} 2 \mathrm{O} \quad \mathrm{T}_{\text {vent }}:=\mathbf{8 0} \cdot \mathrm{F}+\mathbf{4 6 0} \cdot \mathrm{R}$
(IVF Chapter $3-07$ )

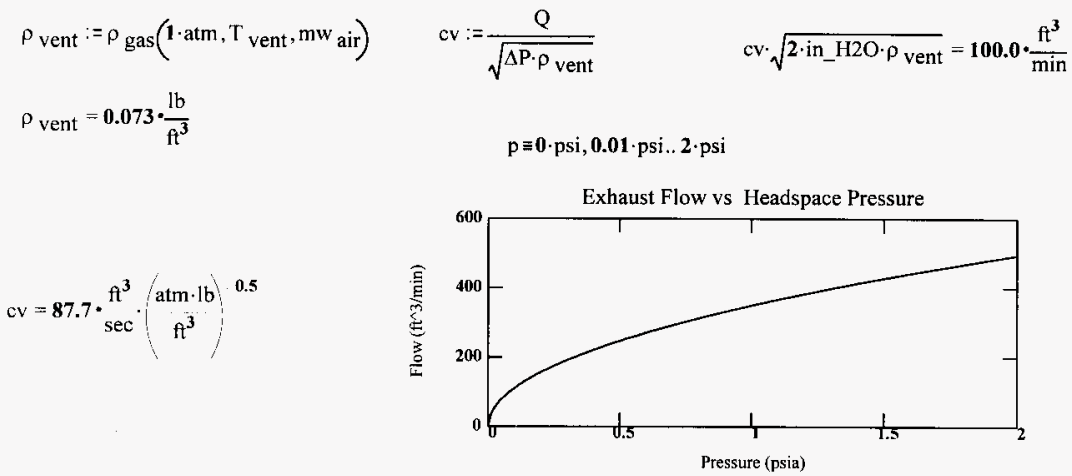

Initialize calculational variables

Number of moles

in the headspace

Initial mass of air in headspace

$$
\mathrm{n}_{\text {air }}{ }^{-\mathrm{P}_{\text {air }} \cdot \mathrm{hsv}} \mathrm{R}_{\text {gas }} \cdot \mathrm{T}_{\text {air }}
$$$$
\mathrm{m}_{\text {air }}-\mathrm{hsv}^{\prime} \rho_{\text {air }}
$$

$\mathrm{n}_{\text {air }}=\mathbf{2 4 7 . 0}$

$m_{\text {air }}=7.16 \cdot 10^{3} \cdot 1 b$ 


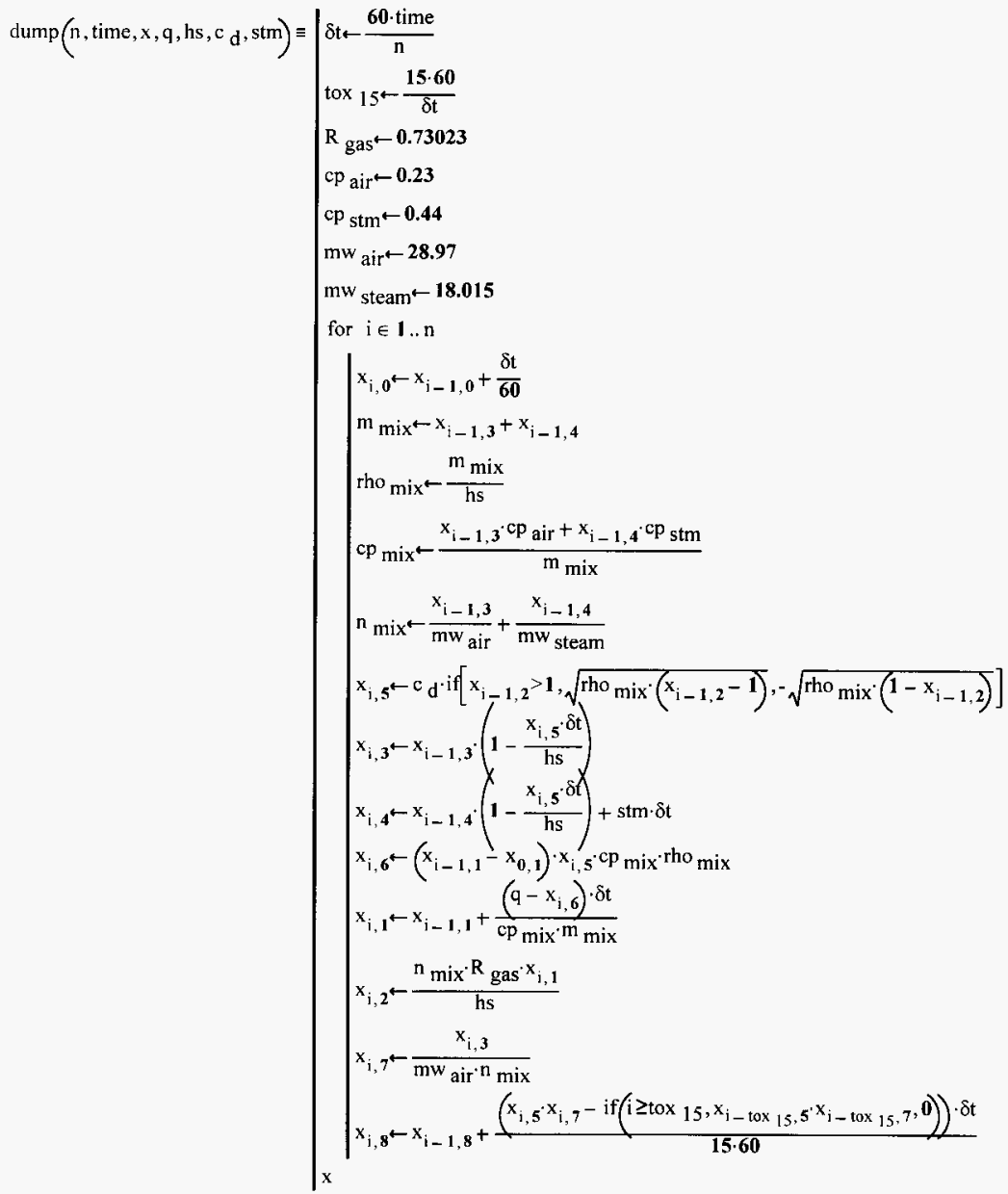


HNF-SD-WM-CN-044, Rev. 2
$x_{0,0}:=0$
time
$x_{0,1}:=\frac{T_{\text {air }}}{R}$
headspace
temperature
$x_{0,4}:=0$
mass of steam
$x_{0,2}:=\frac{P_{\text {air }}}{a t m} \quad$ pressure
$x_{0,3}:=\frac{P_{\text {air }}{ }^{h} h_{s v}}{R_{\text {gas }} T_{\text {air }}} \cdot \frac{\mathrm{mw}_{\text {air }}}{\mathrm{lb}}$
total mass of air
$x_{0,5}:=0$
vent flow
$x_{0,6}:=0$
volume of headspace gas
vented per unit time
$x_{0,7}:=0$
volume of headspace gas vented per unit time$$
x_{0,8}:=0
$$

$$
\mathrm{x}_{\text {save }}:=\mathrm{x}
$$

\section{Calculate transient}

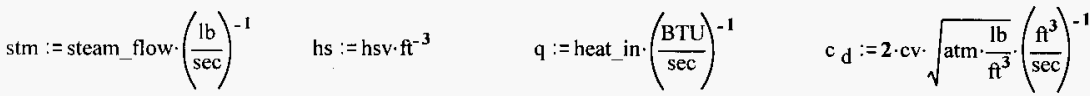

$$
\begin{aligned}
& \text { time }:=500 \quad n:=\frac{\text { time }}{1} \quad i:=1 . . n \quad \frac{15 \cdot n}{\text { time }}=15.0 \\
& \mathrm{x}:=\mathrm{x}_{\text {save }} \quad \mathrm{x}:=\operatorname{dump}\left(\mathrm{n}, \mathrm{time}, \mathrm{x}, \mathrm{q}, \mathrm{hs}, \mathrm{c}_{\mathrm{d}}, \mathrm{stm}\right) \quad \text { tox }:=\mathrm{x}_{\mathrm{i}, 8} \cdot \frac{\mathrm{ft}^{3}}{\sec } \\
& \max (\operatorname{tox})=732.0 \cdot \frac{\mathrm{ft}^{3}}{\min } \\
& x_{n, 1} \cdot R-460 \cdot R=291.8 \cdot F \\
& \left(x_{n, 2}-1\right) \cdot \text { atm }=3.3 \cdot p s i \\
& \mathrm{j}:=\text { floor }\left(\mathrm{n} \cdot \frac{335}{\text { time }}\right) \\
& \max (t o x)=0.345 \cdot \frac{\mathrm{m}^{3}}{\mathrm{sec}} \\
& x_{n, 1} \cdot R=417.7 \cdot K \\
& \left(x_{n, 2}-1\right) \cdot a t m=22.5 \cdot k P a \\
& \mathrm{x}_{\mathrm{j}, \mathbf{7}}=\mathbf{5 . 0 7} \%
\end{aligned}
$$

Exhaust Flow

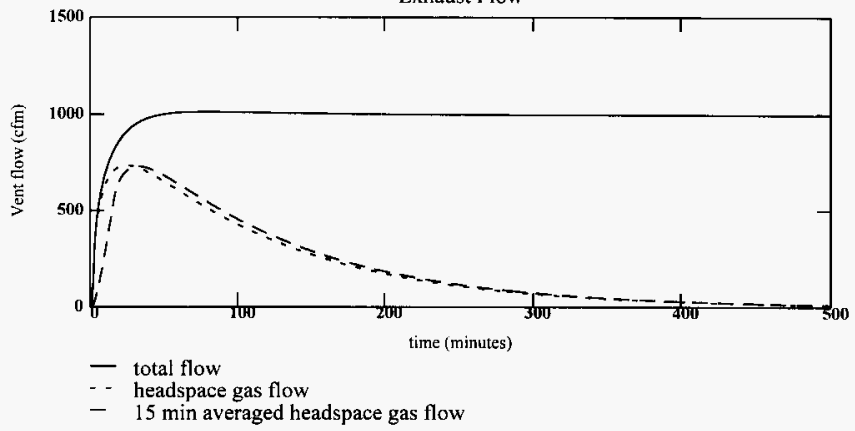


HNF-SD-WM-CN-044, Rev. 2
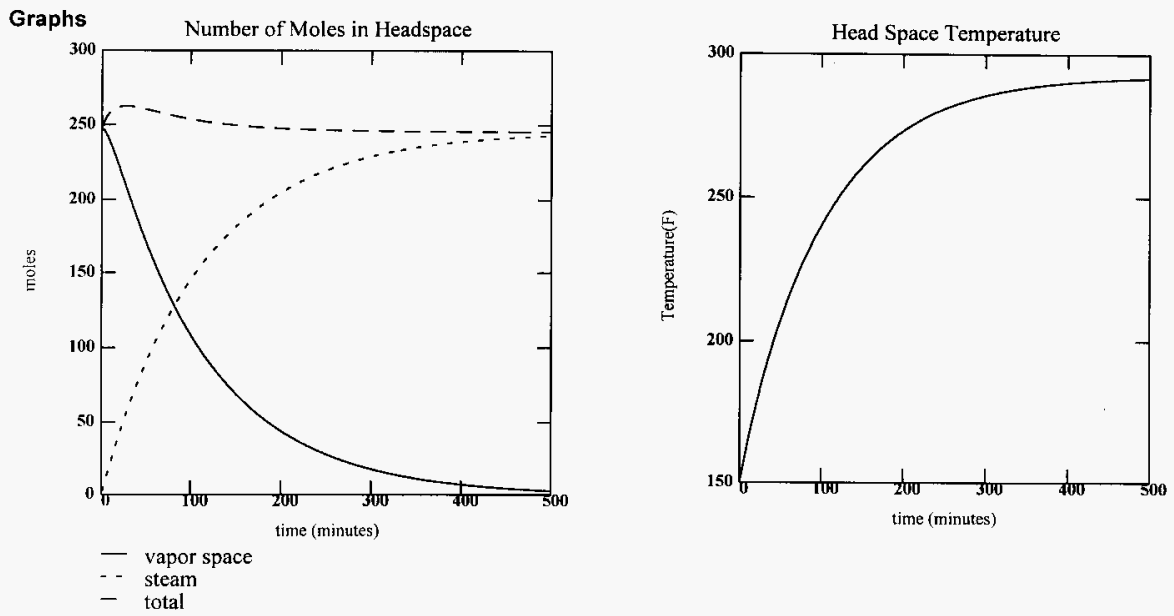

$P_{1}:=x_{i, 2} \cdot a t m$

$$
\begin{aligned}
& \text { rho }_{i} \cdot \frac{\left(x_{i, 3} \mid x_{i, 4}\right) \cdot l b}{h s v} \quad \quad \text { rho }_{n}=0.040 \cdot \frac{\mathrm{lb}}{\mathrm{ft}^{3}} \\
& \rho_{\operatorname{gas}}\left(x_{n, 2} \cdot \operatorname{atm}, x_{n, 1} \cdot R, m_{\text {steam }}\right)=0.040 \cdot \frac{\mathrm{lb}}{\mathrm{ft}^{3}}
\end{aligned}
$$
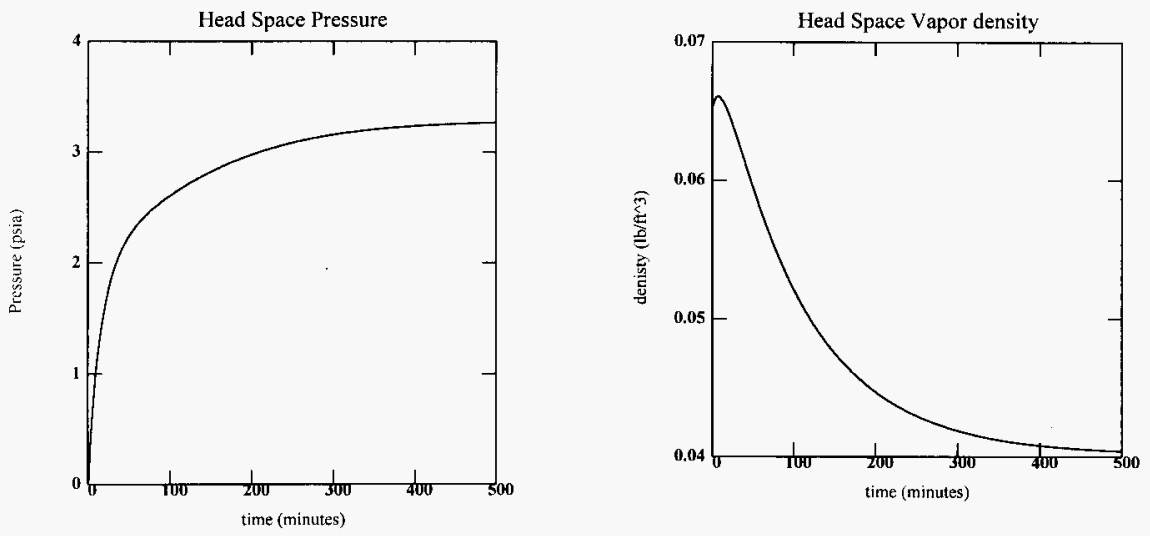


\section{Increased steam inlet temperature}

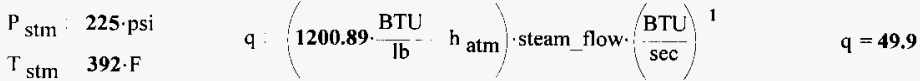

$$
\begin{aligned}
& \text { time } 500 \quad n \text { time } \quad \text { i : } 1 \ldots n \quad \text { t..n } \quad \text { time }=15.0 \\
& \mathrm{x} \quad \mathrm{x}_{\text {save }} \mathrm{x}: \operatorname{dump}\left(\mathrm{n}, \mathrm{time}, \mathrm{x}, \mathrm{q}, \mathrm{hs}, \mathrm{c}_{\mathrm{d}}, \mathrm{stm}\right) \quad \operatorname{tox}_{\mathbf{i}}-\mathrm{x}_{\mathrm{i}, 8^{8}} \mathrm{ft}^{\mathbf{3}} \\
& \begin{array}{cccc}
\max (\text { tox })=750.9 \cdot \frac{\mathrm{ft}^{3}}{\min } & \mathrm{x}_{\mathrm{n}, 1} \cdot \mathrm{R}-\mathbf{4 6 0} \cdot \mathrm{R}=319.1 \cdot \mathrm{F} & \left(\mathrm{x}_{\mathrm{n}, 2}-1\right) \cdot \mathrm{atm}=3.5 \cdot \mathrm{psi} \quad \mathrm{j}:=\text { floor }\left(\mathrm{n} \cdot \frac{325}{\text { time }}\right) \\
\max (\text { to })=0.354 \cdot \frac{\mathrm{m}^{3}}{\mathrm{sec}} & \mathrm{x}_{\mathrm{n}, 1} \cdot \mathrm{R}=432.8 \cdot \mathrm{K} & \left(\mathrm{x}_{\mathrm{n}, 2}-1\right) \cdot \mathrm{atm}=\mathbf{2 4 . 2} \cdot \mathrm{kPa} & \mathrm{x}_{\mathrm{j}, 7}=5.29 \cdot \%
\end{array}
\end{aligned}
$$
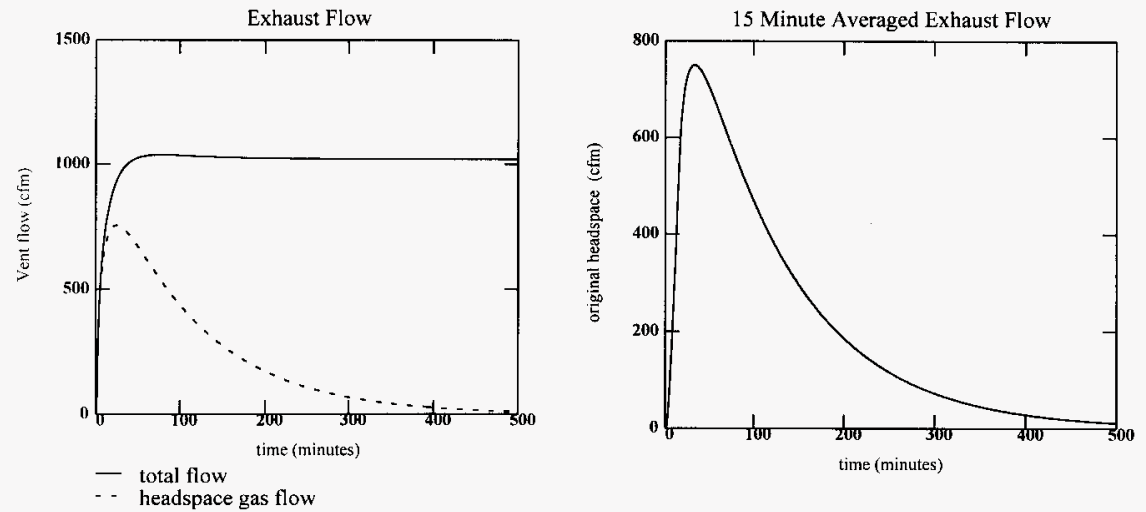
Increased steam flow

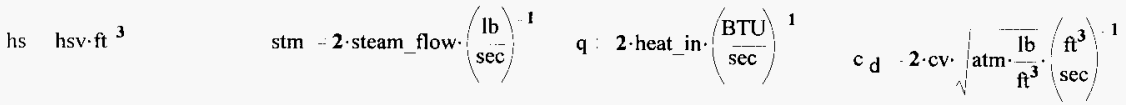

$$
\begin{aligned}
& \text { time } 500 \quad \mathrm{n} \underset{\mathrm{l}}{\mathrm{1}} \mathrm{time} \quad \mathrm{i} \quad 1 . . \mathrm{n} \quad \begin{array}{l}
15 \cdot \mathrm{n} \\
\text { time }
\end{array}=15.0 \\
& x \quad x \text { save } \quad x \operatorname{dump}\left(n, \text { time }, x, q, h s, c_{d}, \operatorname{stm}\right) \quad \text { to } x_{i} \therefore x_{i, 8} \cdot \frac{\mathrm{ft}^{3}}{\text { sec }}
\end{aligned}
$$

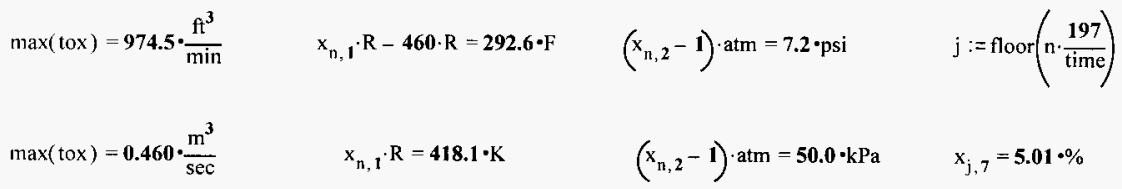
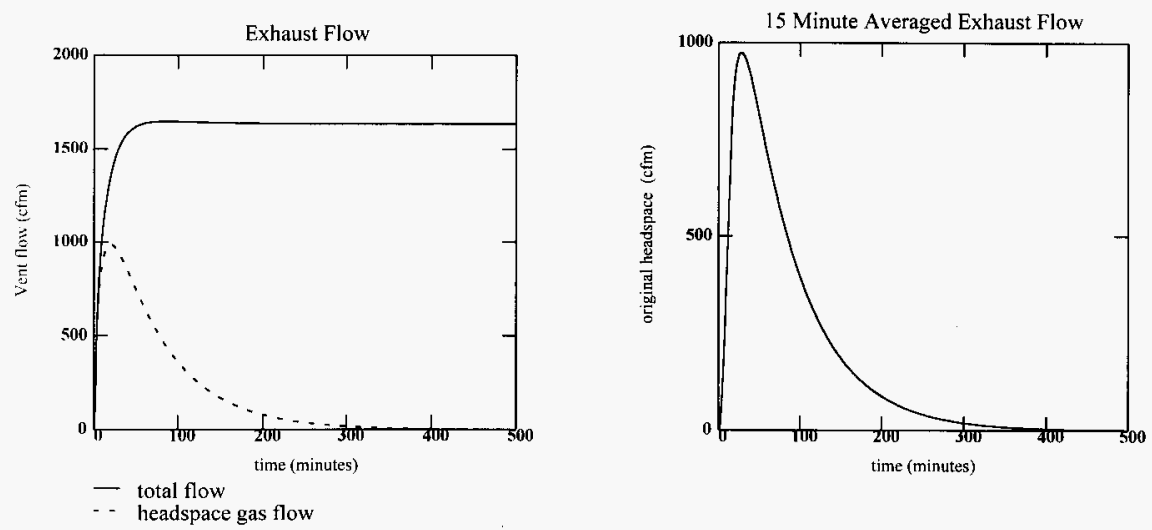
Increased headspace volume

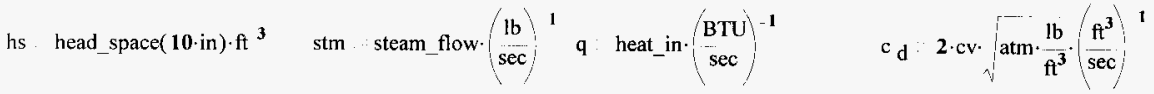

$$
\begin{aligned}
& \text { time } 800 \quad n \cdot \begin{array}{c}
\text { time } \\
1
\end{array} \quad \mathrm{i} \quad 1 . . \mathrm{n} \quad \begin{array}{l}
15 \cdot \mathrm{n} \\
\text { time }
\end{array}=15.0 \\
& x \quad x_{\text {save }} \quad x_{0,3}: \begin{array}{l}
P_{\text {air }} \cdot h s \cdot \mathrm{f}^{3} \text { mw } \\
R_{\text {gas }} \cdot \mathrm{T} \text { air }
\end{array} \\
& \max (\text { tox })=732.7 \cdot \frac{\mathrm{ft}^{3}}{\min } \quad \mathrm{x}_{\mathrm{n}, 1} \cdot \mathrm{R}-460 \cdot \mathrm{R}=291.5 \cdot \mathrm{F} \quad\left(\mathrm{x}_{\mathrm{n}, 2}-1\right) \cdot \mathrm{atm}=3.3 \cdot \mathrm{psi} \quad \mathrm{j}:=\mathrm{floor}\left(\mathrm{n} \cdot \frac{560}{\text { time }}\right) \\
& \max (\text { tox })=0.346 \cdot \frac{\mathrm{m}^{3}}{\mathrm{sec}} \quad \mathrm{x}_{\mathrm{n}, 1} \cdot \mathrm{R}=\mathbf{4 1 7 . 5 \cdot \mathrm { K }} \quad\left(\mathrm{x}_{\mathrm{n}, 2}-1\right) \cdot \mathrm{atm}=22.5 \cdot \mathrm{kPa} \quad \mathrm{x}_{\mathrm{j}, 7}=5.12 \cdot \%
\end{aligned}
$$
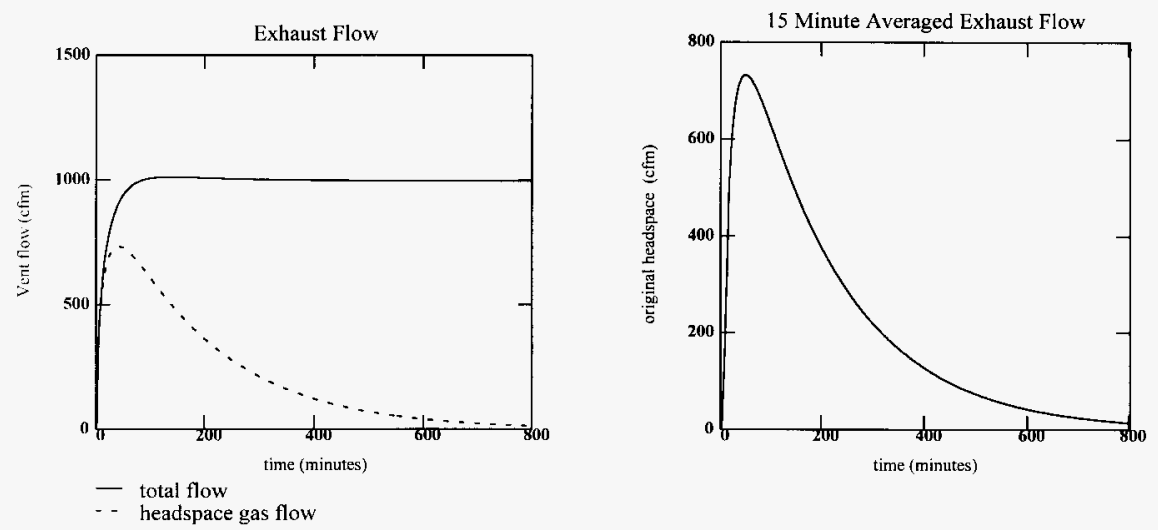


\section{Decreased headspace volume}

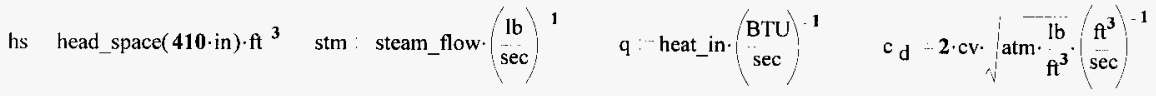

$$
\begin{aligned}
& \text { time } 200 \quad n: \begin{array}{c}
\text { time } \\
1
\end{array} \quad i: 1 . n \quad \frac{15 \cdot n}{\text { time }}=15.0
\end{aligned}
$$

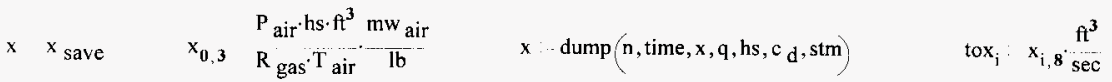

$$
\begin{aligned}
& \max (\text { tox })=709.6 \cdot \frac{\mathrm{ft}^{3}}{\min } \quad \mathrm{x}_{\mathrm{n}, 1} \cdot \mathrm{R}-460 \cdot \mathrm{R}=292.3 \cdot \mathrm{F} \quad\left(\mathrm{x}_{\mathrm{n}, 2}-1\right) \cdot \text { atm }=3.3 \cdot \mathrm{psi} \quad \mathrm{j}:=\text { floor }\left(\mathrm{n} \cdot \frac{113}{\text { time }}\right) \\
& \max (\text { tox })=0.335 \cdot \frac{\mathrm{m}^{3}}{\mathrm{sec}} \quad \mathrm{x}_{\mathrm{n}, 1} \cdot \mathrm{R}=417.9 \cdot \mathrm{K} \quad\left(\mathrm{x}_{\mathrm{n}, 2}-1\right) \cdot \operatorname{atm}=22.6 \cdot \mathrm{kPa} \quad \mathrm{x}_{\mathrm{j}, 7}=5.00 \cdot \%
\end{aligned}
$$
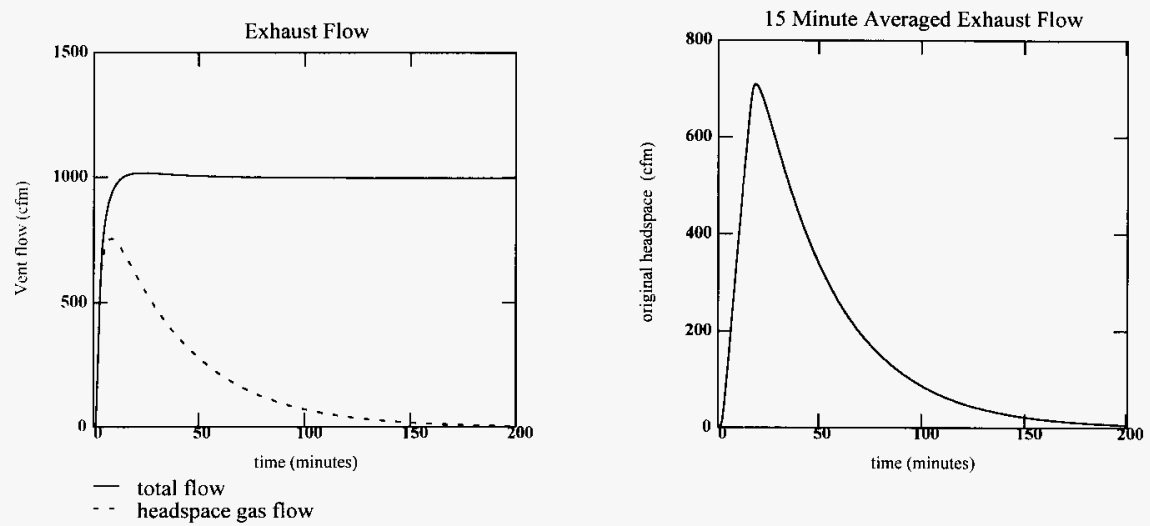


\section{Increase the outlet flow resistance}

hs head_space $(212 \cdot \mathrm{in}) \cdot \mathrm{ft}^{3}$ stm - steam_flow $\cdot\left(\begin{array}{c}\mathrm{lb} \\ \mathrm{sec}\end{array}\right)^{1}$

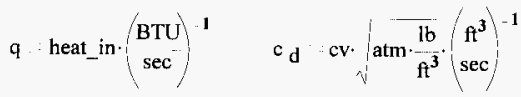

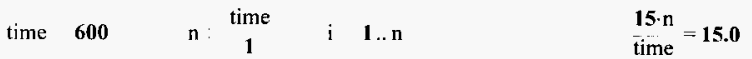
$x \quad x$ save
$\begin{array}{ll}\mathrm{x}_{0,3} & \mathrm{P}_{\text {air }} \cdot \mathrm{hs}^{\mathrm{f}} \cdot \mathrm{ft}^{3} \mathrm{mw} \text { air } \\ \mathrm{R}_{\text {gas }} \cdot \mathrm{T}_{\text {air }}-\mathrm{lb}^{\mathrm{l}}\end{array}$
$x \quad \operatorname{dump}\left(\mathrm{n}\right.$, time, $x, q$, hs, $c_{d}$, stm $)$
$\operatorname{tox}_{i}: x_{i, 8} \cdot f^{3}$
$\max (\operatorname{tox})=491.2 \cdot \frac{\mathrm{ft}^{3}}{\min }$
$x_{n, 1} \cdot R-460 \cdot R=292.4 \cdot F$
$\left(x_{n, 2}-1\right) \cdot a t m=7.2 \cdot p s i$
$\mathrm{j}:=$ floor $\left(\mathrm{n} \cdot \frac{391}{\text { time }}\right)$
$\max (\mathrm{tox})=0.232 \cdot \frac{\mathrm{m}^{3}}{\mathrm{sec}}$
$x_{n, 1} \cdot R=418.0 \cdot K$
$\left(x_{n, 2}-1\right) \cdot a t m=49.7 \cdot k P a$
$x_{j, 7}=5.17 \cdot \%$
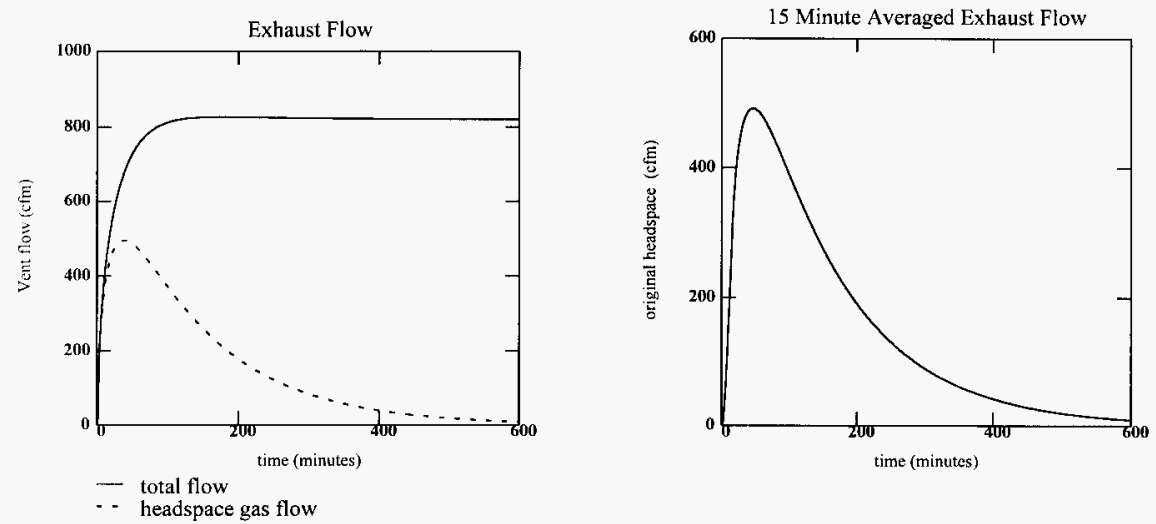


\section{Decrease the outlet flow resistance}

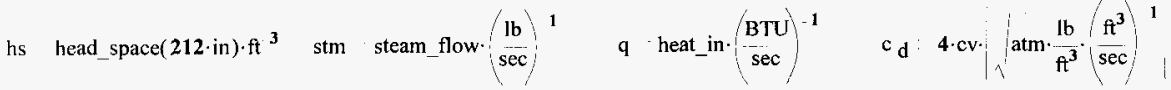

$$
\begin{aligned}
& \text { time } 400 \quad n: \begin{array}{c}
\text { time } \\
1
\end{array} \quad \text { i }: 1 . n \quad \begin{array}{l}
15 \cdot n \\
\text { time }
\end{array}=15.0
\end{aligned}
$$

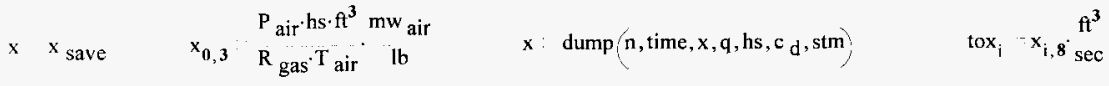

$$
\begin{aligned}
& \begin{array}{llll}
\max (\text { tox })=981.2 \cdot \frac{\mathrm{ft}^{3}}{\min } & \mathrm{x}_{\mathrm{n}, 1} \cdot \mathrm{R}-460 \cdot \mathrm{R}=290.6 \cdot \mathrm{F} & \left(\mathrm{x}_{\mathrm{n}, 2}-1\right) \cdot \mathrm{atm}=1.2 \cdot \mathrm{psi} & \mathrm{j}:=\text { floor }\left(\mathrm{n} \cdot \frac{305}{\text { time }}\right) \\
\max (\text { tox })=0.463 \cdot \frac{\mathrm{m}^{3}}{\mathrm{sec}} & \mathrm{x}_{\mathrm{n}, 1} \cdot \mathrm{R}=417.0 \cdot \mathrm{K} & \left(\mathrm{x}_{\mathrm{n}, 2}-1\right) \cdot \mathrm{atm}=8.1 \cdot \mathrm{kPa} & \mathrm{x}_{\mathrm{j}, 7}=4.94 \cdot 0
\end{array}
\end{aligned}
$$
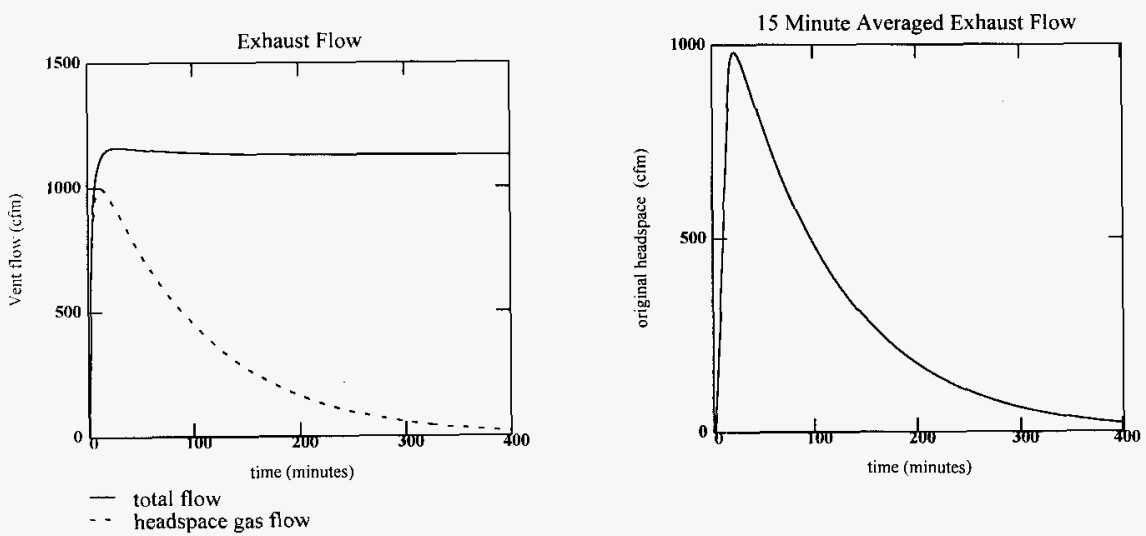
Steam Properties at $150 \mathrm{~F}$ and $290 \mathrm{~F}$ (steam tables)
$\mathrm{T}_{0} \quad \mathbf{1 5 0} \cdot \mathrm{F}$ | $460 \cdot \mathrm{R}$
$\mathrm{P}_{0} \quad$ 3.72.psi
$\mathrm{h}_{0} \quad 1126.1 \cdot \frac{\mathrm{BTU}}{\mathrm{lb}}$
$v_{0}=96.97 \cdot \frac{\mathrm{ft}^{3}}{\mathrm{lb}}$
$T_{1} \quad 290 \cdot F \mid \mathbf{H 6 0} \cdot \mathbf{R}$
$P_{1}:$ 18.psi
$h_{1}-1187.14 \cdot \frac{B T U}{i b}$
$v_{1} \quad 27.293 \cdot \frac{\mathrm{ft}^{3}}{\mathrm{bb}}$

Comparison of the density using the ideal gas law with the steam tables for:
$150 \mathrm{~F}$
$290 \mathrm{~F}$
$\rho_{\text {gas }}\left(\mathrm{P}_{0}, \mathrm{~T}_{0}, \mathrm{mw}_{\text {steam }}\right){ }^{1} v_{0}=0.7 \cdot \%$
$\frac{\rho_{\text {gas }}\left(\mathrm{P}_{1}, \mathrm{~T}_{1}, \mathrm{mw}_{\text {steam }}\right)^{-1}-v_{1}}{v_{1}}=-9.1 \%$

Heat capacity for water (Cengel and Boles, 1994, Table A-2E)

$\mathrm{cp}_{\operatorname{stm}}(\mathrm{T}):=\left(7.700+0.02552 \cdot 10^{-2} \cdot \mathrm{T}+\mathbf{0 . 0 7 7 8 1} \cdot 10^{-5} \cdot \mathrm{T}^{2}-\mathbf{0 . 1 4 7 2} \cdot 10^{-9} \cdot \mathrm{T}^{3}\right) \cdot \frac{\mathrm{BTU}}{\mathrm{lb} \_\mathrm{mole} \cdot \mathrm{R}} \cdot \frac{\mathrm{lb} \_ \text {mole }}{18.015 \cdot \mathrm{lb}}$

Check of $c p$ of the steam against steam tables

$$
\frac{\mathrm{cp} \operatorname{stm}\left(\frac{\mathrm{T}_{0}}{\mathrm{R}}\right)+\mathrm{cp} \operatorname{stm}\left(\frac{\mathrm{T}_{1}}{\mathrm{R}}\right)}{2}=0.45 \cdot \frac{\mathrm{BTU}}{\mathrm{lb} \cdot \mathrm{R}} \quad \frac{\mathrm{h}_{1}-\mathrm{h}_{0}}{\left(\mathrm{~T}_{1}-\mathrm{T}_{0}\right)}=\mathbf{0 . 4 4} \cdot \frac{\mathrm{BTU}}{\mathrm{lb} \cdot \mathrm{R}}
$$

Heat capacity for air (Cengel and Boles, 1994, Table A-2E)

$$
\begin{gathered}
c p_{\text {air }}(T):=\left(6.713+0.02609 \cdot 10^{-2} \cdot T+0.03540 \cdot 10^{-5} \cdot T^{2}-0.8082 \cdot 10^{-9} \cdot T^{3}\right) \cdot \frac{B T U}{l_{b} \text { mole } \cdot R} \cdot \frac{l b \_ \text {mole }}{28.97 \cdot l b} \\
\frac{c p_{\text {air }}\left(\frac{T_{0}}{R}\right)+c p_{\text {air }}\left(\frac{T_{1}}{R}\right)}{2}=0.23 \cdot \frac{\mathrm{BTU}}{\mathrm{lb} \cdot \mathrm{R}}
\end{gathered}
$$

Definition of some units for MathCad
lb_mole $\equiv 1$
$F \equiv R$
$\mathrm{kPa} \equiv 10^{3} \cdot \mathrm{Pa}$
$\mathrm{kJ} \equiv \mathbf{1 0}^{\mathbf{3}} \cdot$ joule
$\mathrm{kg} \_$mole $\equiv \frac{\mathrm{kg}}{\mathrm{lb}} \cdot \mathrm{lb} \_$mole
$\mathrm{C} \equiv \mathrm{K} \quad$ in_ $\mathrm{H} 2 \mathrm{O} \equiv \mathrm{g} \cdot \mathbf{1} \cdot \frac{\mathrm{gm}}{\mathrm{cm}^{3}} \cdot 1 \cdot$ in 
HNF-SD-WM-CN-044 REV 2

This page intentionally left blank. 
HNF-SD-WM-CN-044 REV 2

APPENDIX F

CONSEQUENCE CALCULATION FOR STEAM INTRUSION

F-1 
HNF-SD-WM-CN-044 REV 2

This page intentionally left blank.

F-2 
This appendix includes three sets of data and the associated consequence calculations. The first set is for the full tank, the second for the halffull tank, and the third for the empty tank. The example calculations shown in the body of the narrative in Sections 1.5 through 1.9 are for the half-full tank release, at an average flow rate.

Each consequence calculation set presented here includes two pages. The first page of data, and the second page of the calculation results. The calculational methods are described in the preceding sections of the calculational note. These calculations use data from Appendix E. 
HALF-FULL TANK SCENARIO

Ventilation System Releases

$$
\begin{array}{ll}
Q_{1 a}=0.000979 L & \text { DST } \\
Q_{1 b}=0.005618 \mathrm{~L} & \text { AWF }
\end{array}
$$

Headspace Particulate Loading

$$
\begin{array}{lll}
Q_{2 a}=0.03116 L & \text { DST } \\
Q_{2 b}=0.03116 L & \text { AWF }
\end{array}
$$

Partition Fraction $=1.00 \mathrm{E}-08$

\section{Headspace Volume}

$$
V_{\mathrm{ol}} \mathrm{DST}_{\mathrm{DT}}=3.1 \mathrm{E}+03 \mathrm{~m}^{3}
$$

$\mathrm{Vol}_{\text {AWF }}=3.1 \mathrm{E}+03 \mathrm{~m}^{3}$

Duration and Maximum Flow

$$
\begin{aligned}
t & =1.335 \min ^{2} \\
\text { Flow }_{\max } & =10,345 \mathrm{~m}^{3} / \mathrm{s}
\end{aligned}
$$

\begin{tabular}{|c|c|c|c|c|c|}
\hline & \multicolumn{4}{|c|}{$\chi / Q$ Values $\left(\mathrm{s} / \mathrm{m}^{3}\right)$} & \multirow[t]{2}{*}{ WHC-SD-WM-SARR-016, Rev. 2} \\
\hline & Acute & PM & Chronic & Log. Int. & \\
\hline Onsite & $3.41 E-02$ & $1.13 \mathrm{E}-02$ & 4.03E-04 & 7.51E-03 & \\
\hline Offsite & 2.83E-05 & 2.12E-05 & $1.24 \mathrm{E}-07$ & 1.13E-05 & \\
\hline
\end{tabular}

WHC-SD-WM-CN-054, Rev. 0

WHC-SD-WM-SAR-065, Rev. 0, pg 3.4225

\begin{tabular}{|c|c|c|}
\hline & $\begin{array}{c}\text { Inhalation } \\
\text { (Sv/L) }\end{array}$ & $\begin{array}{l}\text { Ingestion } \\
\left(\mathrm{Sv} \mathrm{m}^{3} / \mathrm{s} \mathrm{L}\right)\end{array}$ \\
\hline DST Liquids & $6.10 \mathrm{E}+03$ & 0.07 \\
\hline DST Solids & $5.30 \mathrm{E}+05$ & 0.48 \\
\hline AWF Liquids & $1.40 \mathrm{E}+03$ & 0.09 \\
\hline AWF Solids & $1.70 \mathrm{E}+06$ & 8.10 \\
\hline
\end{tabular}

Tank level $\quad 5.38 \mathrm{~m}$

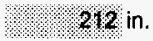

$$
\mathrm{BR}=\begin{gathered}
\text { Breathing Rate } \\
3.30 \mathrm{E}-04 \mathrm{~m}^{3} / \mathrm{s}
\end{gathered}
$$

\section{Unit Liter Doses (ULDs)}

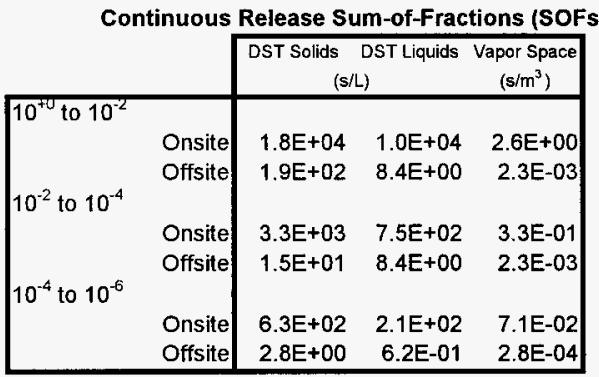

Standard man doing light activity

WHC-SD-WM-SARR-037, Rev. 0

WHC-SD-WM-SARR-011, Rev. 2 
HALF-FULL TANK SCENARIO

Radiological Consequences

\begin{tabular}{|lllll|}
\cline { 3 - 5 } \multicolumn{1}{c|}{} & & HEPA & Particulate & Total \\
\hline \multirow{4}{*}{ DST } & Onsite & $1.5 \mathrm{E}-05$ & $4.7 \mathrm{E}-04$ & $4.9 \mathrm{E}-04$ \\
& Offsite & $2.3 \mathrm{E}-08$ & $7.3 \mathrm{E}-07$ & $7.6 \mathrm{E}-07$ \\
& Onsite & $2.0 \mathrm{E}-05$ & $1.1 \mathrm{E}-04$ & $1.3 \mathrm{E}-04$ \\
& Offsite & $3.5 \mathrm{E}-08$ & $1.9 \mathrm{E}-07$ & $2.3 \mathrm{E}-07$ \\
\hline
\end{tabular}

Toxicological Exposures

\begin{tabular}{|c|c|c|c|c|c|}
\hline & HEPA & Particulate & Gases & Total \\
\hline \multicolumn{6}{|l|}{$10^{+0}$ to $10^{-2}$} \\
\hline \multirow{2}{*}{ DST Average Flow } & Onsite & $4.9 \mathrm{E}-04$ & 1.6E-02 & 4.0E-01 & $4.2 \mathrm{E}-01$ \\
\hline & Offsite & 4.1E-07 & 1.3E-05 & $3.6 \mathrm{E}-04$ & 3.7E-04 \\
\hline \multirow{2}{*}{ DST Maximum Flow } & Onsite & 4.9E-04 & $1.6 \mathrm{E}-02$ & $9.0 \mathrm{E}-01$ & 9.1E-01 \\
\hline & Offsite & 4.1E-07 & 1.3E-05 & 7.9E-04 & 8.1E-04 \\
\hline \multirow{2}{*}{ AWF Average Flow } & Onsite & 2.8E-03 & 1.6E-02 & $4.0 \mathrm{E}-01$ & 4.2E-01 \\
\hline & Offsite & 2.3E-06 & 1.3E-05 & $3.6 \mathrm{E}-04$ & 3.7E-04 \\
\hline \multirow{2}{*}{ AWF Maximum Flow } & Onsite & 2.8E-03 & $1.6 \mathrm{E}-02$ & 9.0E-01 & $9.2 \mathrm{E}-01$ \\
\hline & Offsite & 2.3E-06 & 1.3E-05 & 7.9E-04 & 8.1E-04 \\
\hline \multicolumn{6}{|l|}{$10^{-2}$ to $10^{-4}$} \\
\hline \multirow{2}{*}{ DST Average Flow } & Onsite & 3.7E-05 & 1.2E-03 & 5.1E-02 & 5.2E-02 \\
\hline & Offsite & 4.1E-07 & 1.3E-05 & 3.6E-04 & 3.7E-04 \\
\hline \multirow{2}{*}{ DST Maximum Flow } & Onsite & 3.7E-05 & $1.2 \mathrm{E}-03$ & 1.1E-01 & 1.2E-01 \\
\hline & Offsite & 4.1E-07 & 1.3E-05 & $7.9 E-04$ & 8.1E-04 \\
\hline \multirow{2}{*}{ AWF Average Flow } & Onsite & 2.1E-04 & $1.2 \mathrm{E}-03$ & 5.1E-02 & 5.3E-02 \\
\hline & Offsite & 2.3E-06 & $1.3 \mathrm{E}-05$ & 3.6E-04 & 3.7E-04 \\
\hline \multirow{2}{*}{ AWF Maximum Flow } & Onsite & 2.1E-04 & $1.2 \mathrm{E}-03$ & 1.1E-01 & 1.2E-01 \\
\hline & Offsite & 2.3E-06 & 1.3E-05 & $7.9 \mathrm{E}-04$ & 8.1E-04 \\
\hline \multicolumn{6}{|l|}{$10^{-4}$ to $10^{-6}$} \\
\hline \multirow{2}{*}{ DST Average Flow } & Onsite & 1.0E-05 & 3.3E-04 & 1.1E-02 & 1.1E-02 \\
\hline & Offsite & $3.0 \mathrm{E}-08$ & $9.6 \mathrm{E}-07$ & 4.3E-05 & 4.4E-05 \\
\hline \multirow{2}{*}{ DST Maximum Flow } & Onsite & 1.0E-05 & 3.3E-04 & 2.4E-02 & 2.5E-02 \\
\hline & Offsite & 3.0E-08 & $9.6 \mathrm{E}-07$ & 9.7E-05 & $9.8 \mathrm{E}-05$ \\
\hline \multirow{2}{*}{ AWF Average Flow } & Onsite & 5.9E-05 & $3.3 E-04$ & 1.1E-02 & 1.1E-02 \\
\hline & Offsite & 1.7E-07 & $9.6 \mathrm{E}-07$ & 4.3E-05 & 4.5E-05 \\
\hline \multirow{2}{*}{ AWF Maximum Flow } & Onsite & $5.9 \mathrm{E}-05$ & 3.3E-04 & $2.4 \mathrm{E}-02$ & $2.5 \mathrm{E}-02$ \\
\hline & Offsite & 1.7E-07 & $9.6 \mathrm{E}-07$ & 9.7E-05 & $9.8 \mathrm{E}-05$ \\
\hline
\end{tabular}




\section{EMPTY TANK SCENARIO}

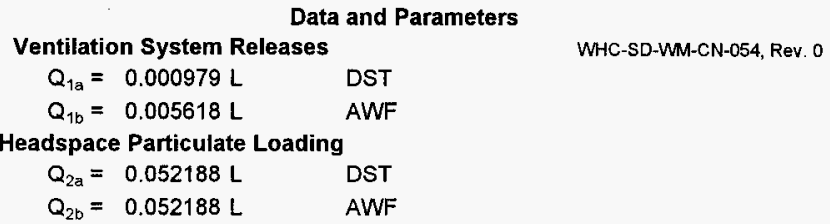

Partition Fraction $=1.00 \mathrm{E}-08$

WHC-SD-WM-SAR-065, Rev. 0, pg 3.4-225

Headspace Volume

$V_{\text {Ol }}$ DST $=5.2 \mathrm{E}+03 \mathrm{~m}^{3}$

$\mathrm{Vol}_{\mathrm{AWF}}=5.2 \mathrm{E}+03 \mathrm{~m}^{3}$

Duration and Maximum Flow

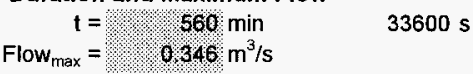

\begin{tabular}{|c|c|c|}
\hline & \multicolumn{2}{|c|}{$\chi / Q$ Values $\left(\mathrm{s} / \mathrm{m}^{3}\right)$} \\
\hline & Acute & PM \\
\hline $\begin{array}{l}\text { Onsite } \\
\text { Offsite }\end{array}$ & $\begin{array}{l}3.41 \mathrm{E}-02 \\
2.83 \mathrm{E}-05 \\
\end{array}$ & $\begin{array}{l}1.13 \mathrm{E}-02 \\
2.12 \mathrm{E}-05\end{array}$ \\
\hline $\mathrm{BR}=$ & \multicolumn{2}{|c|}{$\begin{array}{l}\text { Breathing Rate } \\
3.30 \mathrm{E}-04 \mathrm{~m}^{3} / \mathrm{s}\end{array}$} \\
\hline & \multicolumn{2}{|c|}{ Unit Liter Doses (ULD } \\
\hline & $\begin{array}{l}\text { Inhalation } \\
\text { (Sv/L) }\end{array}$ & $\begin{array}{c}\text { Ingestion } \\
\left(\mathrm{Svm} \mathrm{m}^{3 / \mathrm{L}} \mathrm{L}\right)\end{array}$ \\
\hline DST Liquids & $6.10 \mathrm{E}+03$ & 0.07 \\
\hline DST Solids & $5.30 E+05$ & 0.48 \\
\hline AWF Liquids & $1.40 \mathrm{E}+03$ & 0.09 \\
\hline AWF Solids & $1.70 E+06$ & 8.10 \\
\hline
\end{tabular}

WHC-SD-WM-SARR-016, Rev. 2

Tank level $\quad 0.25 \mathrm{~m}$

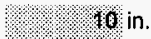

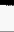

Chronic Log. Int.

Continuous Release Sum-of-Fractions (SOFs)

WHC-SD-WM-SARR-011, Rev. 2

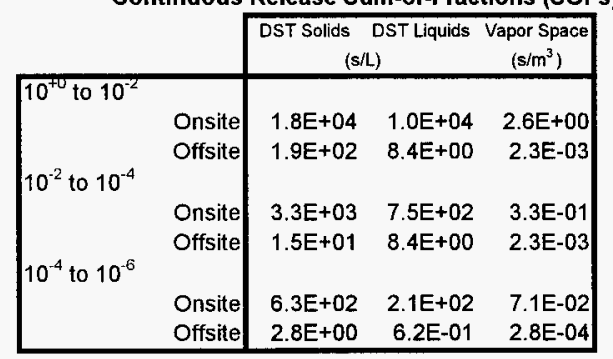

Standard man doing light activity

WHC-SD-WM-SARR-037, Rev. 0 


\section{EMPTY TANK SCENARIO}

\begin{tabular}{|c|c|c|c|c|}
\hline \multicolumn{5}{|c|}{ Radiological Consequences } \\
\hline & & HEPA & Particulate & Total \\
\hline \multirow[t]{2}{*}{ DST } & Onsite & 1.2E-05 & $6.4 \mathrm{E}-04$ & $6.6 \mathrm{E}-04$ \\
\hline & Offsite & 1.7E-08 & $9.0 \mathrm{E}-07$ & 9.1E-07 \\
\hline \multirow[t]{2}{*}{ AWF } & Onsite & $1.6 \mathrm{E}-05$ & $1.5 \mathrm{E}-04$ & $1.6 \mathrm{E}-04$ \\
\hline & Offsite & $2.6 \mathrm{E}-08$ & 2.4E-07 & 2.6E-07 \\
\hline
\end{tabular}

Toxicological Exposures

\begin{tabular}{|c|c|c|c|c|}
\hline & \multirow{2}{*}{\multicolumn{2}{|c|}{ HEPA Particulate }} & \multirow{2}{*}{ Gases } & \multirow{2}{*}{ Total } \\
\hline & & & & \\
\hline \multicolumn{5}{|l|}{$10^{+0}$ to $10^{-2}$} \\
\hline \multirow{2}{*}{$\begin{array}{r}\text { DST Average Flow Onsite } \\
\text { Offsite }\end{array}$} & 2.9E-04 & $1.6 \mathrm{E}-02$ & 4.0E-01 & 4.2E-01 \\
\hline & 2.4E-07 & $1.3 \mathrm{E}-05$ & $3.6 \mathrm{E}-04$ & 3.7E-04 \\
\hline \multirow{2}{*}{ DST Maximum Flow } & $2.9 \mathrm{E}-04$ & $1.6 \mathrm{E}-02$ & $9.0 \mathrm{E}-01$ & 9.2E-01 \\
\hline & 2.4E-07 & 1.3E-05 & 8.0E-04 & 8.1E-04 \\
\hline \multirow{2}{*}{ AWF Average Flow } & 1.7E-03 & $1.6 \mathrm{E}-02$ & 4.0E-01 & 4.2E-01 \\
\hline & $1.4 \mathrm{E}-06$ & $1.3 \mathrm{E}-05$ & $3.6 \mathrm{E}-04$ & 3.7E-04 \\
\hline \multirow{2}{*}{ AWF Maximum Flow } & 1.7E-03 & $1.6 \mathrm{E}-02$ & $9.0 \mathrm{E}-01$ & $9.2 \mathrm{E}-01$ \\
\hline & $1.4 \mathrm{E}-06$ & 1.3E-05 & 8.0E-04 & 8.1E-04 \\
\hline \multicolumn{5}{|l|}{$10^{-2}$ to $10^{-4}$} \\
\hline \multirow{2}{*}{$\begin{array}{r}\text { DST Average Flow Onsite } \\
\text { Offsite }\end{array}$} & $2.2 E-05$ & $1.2 \mathrm{E}-03$ & 5.1E-02 & 5.2E-02 \\
\hline & $2.4 \mathrm{E}-07$ & $1.3 \mathrm{E}-05$ & $3.6 \mathrm{E}-04$ & 3.7E-04 \\
\hline \multirow{2}{*}{ DST Maximum Flow } & 2.2E-05 & 1.2E-03 & 1.1E-01 & 1.2E-01 \\
\hline & 2.4E-07 & 1.3E-05 & $8.0 \mathrm{E}-04$ & 8.1E-04 \\
\hline \multirow{2}{*}{ AWF Average Flow } & $1.3 \mathrm{E}-04$ & $1.2 \mathrm{E}-03$ & $5.1 \mathrm{E}-02$ & 5.3E-02 \\
\hline & 1.4E-06 & 1.3E-05 & 3.6E-04 & 3.7E-04 \\
\hline \multirow{2}{*}{ AWF Maximum Flow } & 1.3E-04 & $1.2 E-03$ & 1.1E-01 & 1.2E-01 \\
\hline & $1.4 \mathrm{E}-06$ & 1.3E-05 & $8.0 E=04$ & 8.1E-04 \\
\hline \multicolumn{5}{|l|}{$10^{-4}$ to $10^{-6}$} \\
\hline DST Average Flow Onsite & $6.1 E-06$ & 3.3E-04 & 1.1E-02 & 1.1E-02 \\
\hline Offsite & $1.8 E-08$ & $9.6 \mathrm{E}-07$ & 4.3E-05 & 4.4E-05 \\
\hline \multirow{2}{*}{ DST Maximum Flow } & 6.1E-06 & 3.3E-04 & 2.5E-02 & 2.5E-02 \\
\hline & $1.8 \mathrm{E}-08$ & $9.6 \mathrm{E}-07$ & $9.7 E-05$ & $9.8 \mathrm{E}-05$ \\
\hline \multirow{2}{*}{ AWF Average Flow } & $3.5 E-05$ & 3.3E-04 & 1.1E-02 & 1.1E-02 \\
\hline & $1.0 \mathrm{E}-07$ & $9.6 E-07$ & 4.3E-05 & 4.5E-05 \\
\hline \multirow{2}{*}{$\begin{array}{r}\text { AWF Maximum Flow Onsite } \\
\text { Offsite }\end{array}$} & 3.5E-05 & 3.3E-04 & $2.5 \mathrm{E}-02$ & 2.5E-02 \\
\hline & 1.0E-07 & $9.6 \mathrm{E}-07$ & 9.7E-05 & $9.8 \mathrm{E}-05$ \\
\hline
\end{tabular}




\section{FULL TANK SCENARIO}

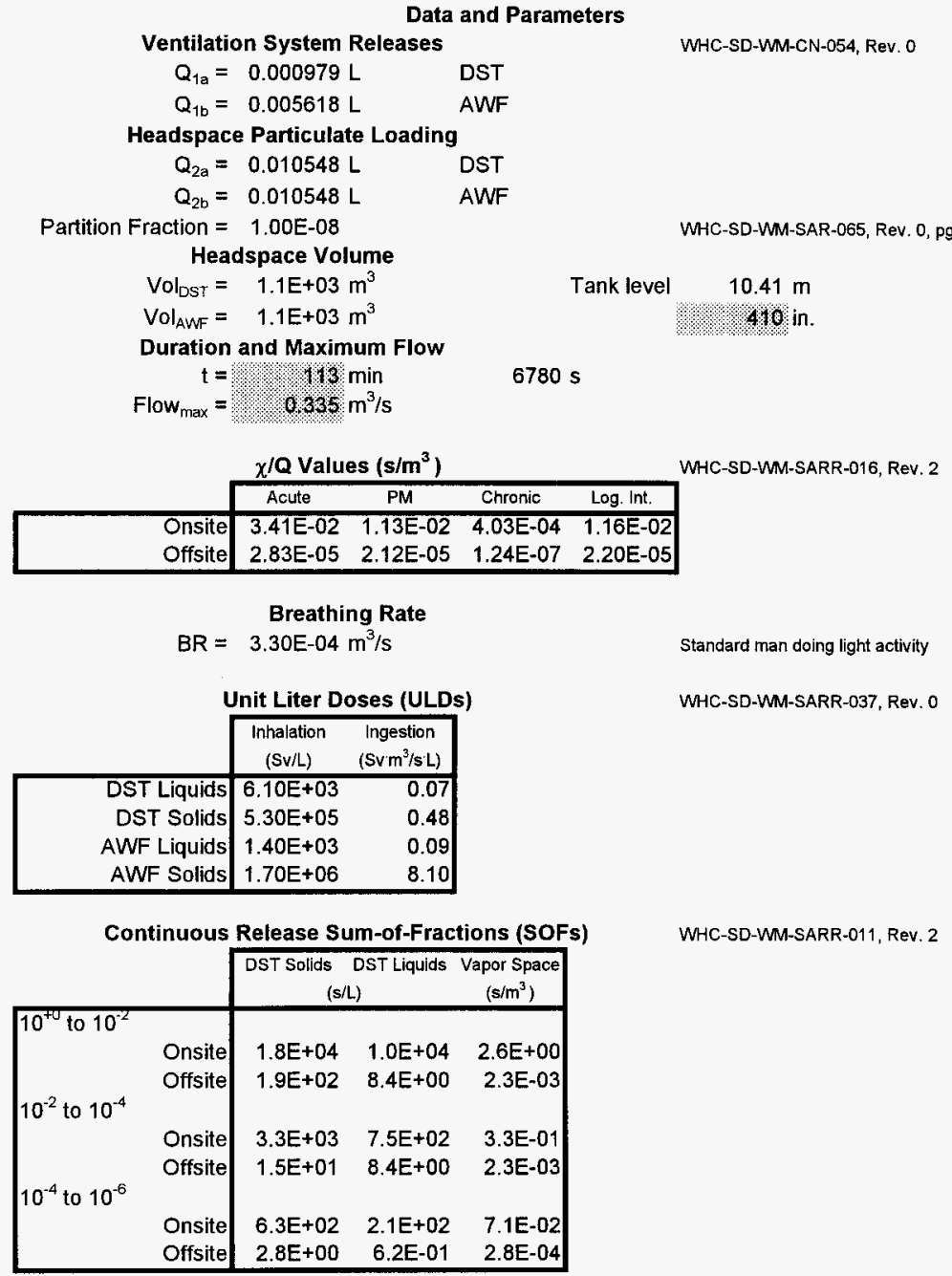


FULL TANK SCENARIO

Radiological Consequences

\begin{tabular}{|ll|lll|}
\cline { 3 - 5 } \multicolumn{1}{c|}{} & & HEPA & Particulate & Total \\
\hline \multirow{4}{*}{ AWF } & Onsite & $2.3 \mathrm{E}-05$ & $2.5 \mathrm{E}-04$ & $2.7 \mathrm{E}-04$ \\
& Offsite & $4.5 \mathrm{E}-08$ & $4.8 \mathrm{E}-07$ & $5.3 \mathrm{E}-07$ \\
& Onsite & $3.0 \mathrm{E}-05$ & $5.6 \mathrm{E}-05$ & $8.6 \mathrm{E}-05$ \\
& Offsite & $6.8 \mathrm{E}-08$ & $1.3 \mathrm{E}-07$ & $2.0 \mathrm{E}-07$ \\
\hline
\end{tabular}

Toxicological Exposures

\begin{tabular}{|c|c|c|c|c|c|}
\hline & HEPA & Particulate & Gases & Total \\
\hline \multicolumn{6}{|l|}{$10^{+0}$ to $10^{-2}$} \\
\hline \multirow{2}{*}{ DST Average Flow } & Onsite & $1.4 \mathrm{E}-03$ & 1.6E-02 & 4.0E-01 & $4.2 \mathrm{E}-01$ \\
\hline & Offsite & 1.2E-06 & 1.3E-05 & 3.6E-04 & 3.7E-04 \\
\hline \multirow{2}{*}{ DST Maximum Flow } & Onsite & 1.4E-03 & 1.6E-02 & 8.7E-01 & $8.9 \mathrm{E}-01$ \\
\hline & Offsite & 1.2E-06 & 1.3E-05 & 7.7E-04 & $7.8 E-04$ \\
\hline \multirow{2}{*}{ AWF Average Flow } & Onsite & 8.3E-03 & 1.6E-02 & 4.0E-01 & 4.3E-01 \\
\hline & Offsite & $7.0 \mathrm{E}-06$ & 1.3E-05 & $3.6 \mathrm{E}-04$ & $3.8 E-04$ \\
\hline \multirow{2}{*}{ AWF Maximum Flow } & Onsite & 8.3E-03 & 1.6E-02 & 8.7E-01 & 8.9E-01 \\
\hline & Offsite & 7.0E-06 & 1.3E-05 & 7.7E-04 & 7.9E-04 \\
\hline \multicolumn{6}{|c|}{$10^{-2}$ to $10^{-4}$} \\
\hline \multirow{2}{*}{ DST Average Flow } & Onsite & 1.1E-04 & 1.2E-03 & 5.1E-02 & 5.3E-02 \\
\hline & Offsite & $1.2 \mathrm{E}-06$ & 1.3E-05 & $3.6 \mathrm{E}-04$ & $3.7 \mathrm{E}-04$ \\
\hline \multirow{2}{*}{ DST Maximum Flow } & Onsite & 1.1E-04 & 1.2E-03 & 1.1E-01 & 1.1E-01 \\
\hline & Offsite & 1.2E-06 & 1.3E-05 & 7.7E-04 & $7.8 \mathrm{E}-04$ \\
\hline \multirow{2}{*}{ AWF Average Flow } & Onsite & $6.2 \mathrm{E}-04$ & 1.2E-03 & 5.1E-02 & $5.3 \mathrm{E}-02$ \\
\hline & Offsite & 7.0E-06 & 1.3E-05 & $3.6 \mathrm{E}-04$ & $3.8 \mathrm{E}-04$ \\
\hline \multirow{2}{*}{ AWF Maximum Flow } & Onsite & $6.2 \mathrm{E}-04$ & 1.2E-03 & 1.1E-01 & $1.1 \mathrm{E}-01$ \\
\hline & Offsite & 7.0E-06 & 1.3E-05 & 7.7E-04 & $7.9 \mathrm{E}-04$ \\
\hline \multicolumn{6}{|l|}{$10^{-4}$ to $10^{-6}$} \\
\hline \multirow{2}{*}{ DST Average Flow } & Onsite & $3.0 \mathrm{E}-05$ & 3.3E-04 & 1.1E-02 & $1.1 \mathrm{E}-02$ \\
\hline & Offsite & $9.0 \mathrm{E}-08$ & $9.6 \mathrm{E}-07$ & 4.4E-05 & 4.5E-05 \\
\hline \multirow{2}{*}{ DST Maximum Flow } & Onsite & 3.0E-05 & 3.3E-04 & $2.4 \mathrm{E}-02$ & $2.4 \mathrm{E}-02$ \\
\hline & Offsite & $9.0 \mathrm{E}-08$ & 9.6E-07 & 9.4E-05 & $9.5 \mathrm{E}-05$ \\
\hline \multirow{2}{*}{ AWF Average Flow } & Onsite & 1.7E-04 & $3.3 \mathrm{E}-04$ & 1.1E-02 & $1.2 \mathrm{E}-02$ \\
\hline & Offsite & 5.1E-07 & 9.6E-07 & 4.4E-05 & 4.5E-05 \\
\hline \multirow{2}{*}{ AWF Maximum Flow } & Onsite & 1.7E-04 & 3.3E-04 & 2.4E-02 & $2.4 \mathrm{E}-02$ \\
\hline & Offsite & 5.1E-07 & $9.6 \mathrm{E}-07$ & 9.4E-05 & 9.5E-05 \\
\hline
\end{tabular}


HNF-SD-WM-CN-044 REV 2

This page intentionally left blank. 
HNF-SD-WM-CN-044 REV 2

APPENDIX G

PEER REVIEW AND HEDOP REVIEW CHECKLISTS

G-1 
HNF-SD-WM-CN-044 REV 2

This page intentionally left blank. 


\section{CHECKLIST FOR PEER REVIEW}

Document Reviewed: Calculation Notes that Support Accident Scenario and Consequence Development for the Steam Intrusion from Interfacing Systems Accident

Scope of Review: Entire document

Yes No NA

[ ] [ ] [ [ ] * Previous reviews complete and cover analysis, up to scope of this review, with no gaps.

[a] [ ] [ ] Problem completely defined.

$[\mathbf{a}][][]$

$[$ [ᄆ] [][]

$[$ ] $[$ ] $[\mathbf{0}]$

Accident scenarios developed in a clear and logical manner.

Necessary assumptions explicitly stated and supported.

[曰] [][] Computer codes and data files documented.

$[\mathbf{a}][][]$

Data used in calculations explicitly stated in document.

Data checked for consistency with original source information as applicable.

[a] [ ] [ ] Mathematical derivations checked including dimensional consistency of results.

[ם] [ ] [ ] Models appropriate and used within range of validity or use outside range of established validity justified.

[a] [ ] [ ] Hand calculations checked for errors. Spreadsheet results should be treated exactly the same as hand calculations.

[0] [ ] [ ] Software input correct and consistent with document reviewed.

[a] [ ] [ ] Software output consistent with input and with results reported in document reviewed.

[ש] [ ] [ ] Limits/criteria/guidelines applied to analysis results are appropriate and referenced. Limits/criteria/guidelines checked against references.

[ם] [ ] [ ] Safety margins consistent with good engineering practices.

[ם] [ ] [ ] Conclusions consistent with analytical results and applicable limits.

[a] [ ] [ ] Results and conclusions address all points required in the problem statement.

[ם] [ ] [ ] Format consistent with appropriate NRC Regulatory Guide or other standards

[ ] [a]* Review calculations, comments, and/or notes are attached.

\section{[a] [ ] [ ] Document approved.}

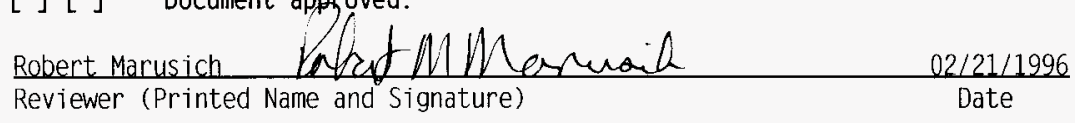

* Any calculations, comments, or notes generated as part of this review should be signed, dated and attached to this checklist. Such material should be iabeled and recorded in such a manner as to be intelligible to a technically qualified third party. 


\section{HEDOP REVIEW CHECKLIST \\ for \\ Radiological and Nonradiological Release Calculations}

Document reviewed (include title or description of calculation, document number, author, and date, as applicable):

Calculation Notes That Support Accident Scenario and Consequence Development for the Steam Intrusion from Interfacing Systems Accident, G.W. Ryan and R.J. Van Vleet, HNF-SD-WM-CN-044 Rev 2, February 1997

Submitted by: R.J. Van Vleet

Date Submitted: $2 / 21 / 97$

Scope of Review: entire document

YES $\quad N O * \quad N / A$

[4] [ ] [ ] 1. A detailed technical review and approval of the environmental transport and dose calculation portion of the analysis has been performed and documented.

DA [ ] [ ] 2. Detailed technical review(s) and approval(s) of scenario and

4 [ ] [ ] 3. HEDOP-approved code(s) were used.

[] [] [] 4. Receptor locations were selected according to HEDOP recommendations.

ए [ ] [ ] 5. A11 applicable environmental pathways and code options were included and are appropriate for the calculations.

(4] [ ] 6. Hanford site data were used.

Q [ ] [ ] 7. Model adjustments external to the computer program were justified and performed correctly.

4 [ ] [ ] 8. The analysis is consistent with HEDOP recommendations.

[] 9. Supporting notes, calculations, comments, comment resolutions, or other information is attached. (Use the "Page 1 of $X$ " page numbering format and sign and date each added page.)

$\$ 4$ [ 10. Approval is granted on behalf of the Hanford Environmental Dose Overview Panel.

* Al1 "NO" responses must be explained and use of nonstandard methods justified.

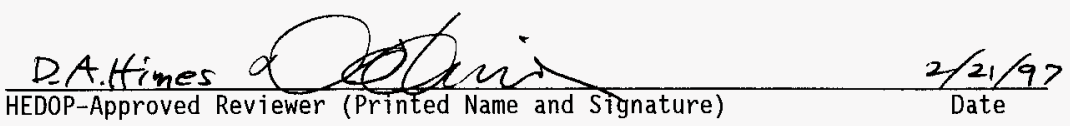

COMMENTS (add additional signed and dated pages if necessary):

The $2 h$ (PM) $\% / Q$ conld hqve been used in the Full Tank scenario instand of interpolating below 2 hours. The differeuce is not significant, however, $a n d$ is in a conservative direction. 